\author{
Dominika Burdzy \\ (Jan Kochanowski University in Kielce, Poland) \\ http://orcid.org/0000-0001-7807-5414 \\ E-mail: dburdzy@ujk.edu.pl
}

\title{
Kasata klasztoru dominikanów przy kościele św. Jakuba w Sandomierzu w 1864 r. i jej konsekwencje
}

\section{The Dissolution of the Dominican Convent at the St. James Church in Sandomierz in 1864 and its Consequences}

\begin{abstract}
The dissolution of the Dominican convent at the St. James Church was conducted on November 8, 1864. This was not an exception in the Kingdom of Poland at that time, when many other religious institutions were dissolved as well. To achieve the effect of full surprise the dissolution was conducted according to an arbitrarily fixed pattern. The friars were transported to a permanent ${ }^{1}$ monastery in Klimontów. Only the then vice Prior was left at the St. James Church to ensure the continuity of worship until the appointment of a diocesan priest. Also, the arch-confraternity of the Rosary was left at the church with the aim of supporting the cult of Mary, illuminating the altars and visiting the sick.

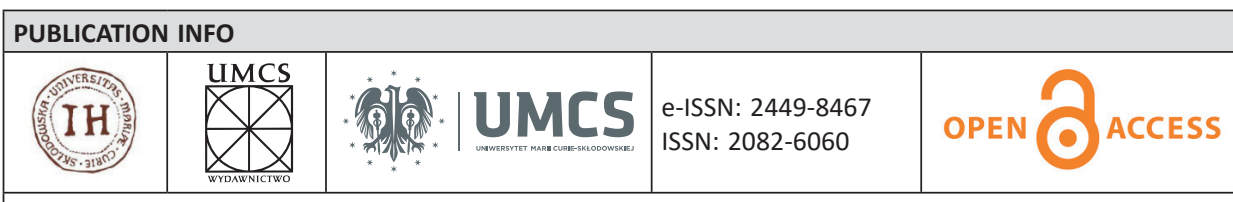

THE AUTHOR'S ADDRESS: Dominika Burdzy, the Institute of History of the Jan Kochanowski University in Kielce, 17 Uniwersytecka Street, Kielce 25-406, Poland

SOURCE OF FUNDING: Funding for Young Researchers of the Institute of History of the Jan Kochanowski University in Kielce

\begin{tabular}{|l|l|l|l|}
\hline $\begin{array}{l}\text { SUBMITTED: } \\
\text { 2020.05.24 }\end{array}$ & $\begin{array}{l}\text { ACCEPTED: } \\
2020.11 .17\end{array}$ & $\begin{array}{l}\text { PUBLISHED ONLINE: } \\
2021.06 .30\end{array}$ \\
\hline $\begin{array}{l}\text { WEBSITE OF THE JOURNAL: } \\
\text { https://journals.umcs.pl/rh }\end{array}$ & $\begin{array}{l}\text { EDITORIAL } \\
\text { COMMITTEE E-mail: } \\
\text { reshistorica@umcs.pl }\end{array}$ & Crossref dol \\
\hline
\end{tabular}
\end{abstract}

1 Approved by the Russian authorities 
The authority over the temple was passed into the hands of the Bishop of Sandomierz, whose responsibility was to choose a diocesan priest with the title of Rector to perform pastoral duties.

For the acquisition of the assets a committee was appointed which included Economic Assessor at the Provincial Government of Radom, President of the city of Sandomierz and Dean of Sandomierz. All the activities were conducted in the presence of Dominican Prior Paulin Machnicki. A detailed report was drawn up which described the buildings and lands belonging to the Dominicans in Sandomierz as well as the farms in Gołębice and Jugoszów. The property was acquired for the benefit of the Kingdom of Poland.

Key words: the dissolution of the Dominican monastery in 1864, Dominikan Order, Sandomierz, Klimontów, the monastery's library, the archconfraternity of the Rosary, S. Jacob church, Sandomierz's diocese

\section{STRESZCZENIE}

Kasata dominikańskiego klasztoru przy kościele św. Jakuba, tak jak innych placówek zakonnych w całym Królestwie Polskim, nastąpiła 8 listopada 1864 r. według odgórnie ustalonego schematu, dzięki czemu chciano uzyskać pełne zaskoczenie. Zakonnicy zostali przewiezieni do klasztoru etatowego w Klimontowie. Przy kościele św. Jakuba pozostawiono dotychczasowego podprzeora, który miał zadbać o ciągłość nabożeństw aż do momentu wyznaczenia na to miejsce duchownego diecezjalnego. Przy kościele pozostało również arcybractwo różańcowe, którego celem było podtrzymywanie kultu maryjnego, oświetlanie ołtarzy i wizytowanie chorych. Zwierzchnictwo nad świątynią przeszło w ręce biskupa sandomierskiego, który miał wyznaczać spośród duchowieństwa diecezjalnego kapłana z tytułem rektora do pełnienia obowiązków duszpasterskich.

W przejęciu majątku brała udział komisja, w skład której wchodzili asesor ekonomiczny przy Rządzie Gubernialnym Radomskim, prezydent miasta Sandomierza oraz dziekan sandomierski. Przy wszystkich czynnościach obecny był przeor dominikanów Paulin Machnicki. W szczegółowym protokole sporządzonym w momencie kasaty opisano zabudowania i grunty należące do dominikanów, które znajdowały się w Sandomierzu, a także folwarki w Gołębicach i Jugoszowie. Majątek ten został przejęty na rzecz Skarbu Królestwa Polskiego.

Słowa kluczowe: kasata klasztoru 1864 r., dominikanie, Sandomierz, Klimontów, biblioteka klasztorna, arcybractwo różańcowe, kościół św. Jakuba, diecezja sandomierska

\section{WSTĘP}

Kasata sandomierskiego klasztoru nie była przedmiotem dotychczasowych badań, wzmianki na jej temat pojawiały się jedynie w opracowaniach dotyczących realizacji ukazu w całym Królestwie Polskim².

2 P.P. Gach, Kasaty zakonów na ziemiach polskich dawnej Rzeczypospolitej i Ślaska 17731914, Lublin 1984, s. 175-204; idem, Zakony w diecezji kieleckiej 1905-1914, „Nasza Przeszłość" 1983, 59, s. 165-213; idem, Mienie polskich zakonów i jego losy w XIX wieku, Rzym 1979, s. 57-59; idem, Struktury i działalność duszpasterska zakonów męskich na ziemiach dawnej 
Podobnie w artykułach biskupa Walentego Wójcika przebieg kasat w diecezji sandomierskiej został omówiony w oparciu o wybrane klasztory, wśród których brak konwentu przy kościele św. Jakuba, a zdawkowe informacje na jego temat pojawiają się niejako w tle omawianych wydarzeń ${ }^{3}$. Nieco więcej danych podała $w$ swoich pracach Elżbieta Orzechowska ${ }^{4}$, porównując sytuację dominikanów z innymi skasowanymi klasztorami w diecezji. Zamknięcie sandomierskiego klasztoru odnotował Paweł Kielar, omawiając kasaty dominikanów w całym okresie rozbiorowym $^{5}$. W jednym zdaniu zamknięto problem zniesienia klasztorów dominikanów i reformatów w nowszej monografii Sandomierza ${ }^{6}$, zaś Melchior

Rzeczypospolitej i Ślaska w latach 1773-1914, Lublin 1999; idem, Zakony w Europie Środkowo-Wschodniej (1773-1914), w: Zakony i klasztory w Europie Środkowo-Wschodniej X-XX wiek. Materiaty z międzynarodowego seminarium pt. Atlas ruchu zakonnego w Europie Środkowo-Wschodniej X-XX wiek. Lublin, 25-27 listopada 1993, red. H. Gapski, J. Kłoczowski, Lublin 1999, s. 27-45; idem, Le soppressioni dei Regolari (1773-1914) nella cartografia e nella recente storiografia polacca, in: Le inchieste Europee sui beni ecclesiastici (confronti regionali secc. XVI-XIX), red. G. Poli, Bari 2005, s. 207-228.

3 W. Wójcik, Tak zwana reforma klasztorów w 1864 roku na terenie diecezji sandomierskiej, „Archiwa, Biblioteki i Muzea Kościelne” [dalej: „ABMK”] 1971, 23, s. 345, 351; idem, Wtaczenie zbiorów poklasztornych do Biblioteki Seminarium Duchownego w Sandomierzu, "ABMK" $1960,1,2$, s. 50-65.

4 E. Orzechowska, Własność poklasztorna w diecezji sandomierskiej po ukazie z 8 XI 1864 r., „Studia Sandomierskie” [dalej: „StSa”] 1983, 31, 2, s. 191-212. Autorka ta opracowała inne zagadnienia dotyczące duchowieństwa diecezji sandomierskiej w czasie powstania styczniowego: eadem, Duchowieństwo diecezji sandomierskiej w prowincjonalnej organizacji spiskowej przed wybuchem powstania styczniowego (1861-1862), „StSa” 1983-1984, 4, s. 159-184; E. Orzechowska, Duchowieństwo diecezji sandomierskiej po wprowadzeniu stanu wojennego do wybuchu powstania styczniowego, „StSa” 1985-1989, 5, s. 419-442; eadem, Aresztowania wśród duchowieństwa diecezji sandomierskiej w dobie powstania styczniowego (1863-1866), "StSa” 1997-2000, 7, s. 185-233; eadem, Duchowni sandomierscy na syberyjskim wygnaniu za udziat w powstaniu styczniowym, „Rocznik Świętokrzyski” 1994, 21, s. 25-42; eadem, Radomscy bernardyni w dobie powstania styczniowego, Radom 2008. Kwestia uczestnictwa w powstaniu dwóch kleryków dominikańskich, którzy przybyli do Sandomierza z klasztoru lubelskiego, została poruszona w opracowaniach: S. Gajewski, Kasata klasztorów w diecezji lubelskiej w roku 1864, "Roczniki Humanistyczne” 1973, 21, 2, s. 351-390; idem, Ostatnie klasztory diecezji lubelskiej w XIX wieku, „Roczniki Humanistyczne” 1974, 22, 2, s. 185-214; idem, Własność poklasztorna w diecezji lubelskiej w II pot. XIX wieku, "Roczniki Humanistyczne” 1975, 23, 2, s. 219-231; E. Niebelski, Nieprzejednani wrogowie Rosji. Duchowieństwo lubelskie i podlaskie w powstaniu 1863 roku i na zestaniu, Lublin 2008; idem, Tunka. Syberyjskie losy księży zesłańców 1863 roku, Wrocław 2011.

5 P. Kielar, Rozbiory i kasaty prowincji dominikanów polskich w latach 1772-1914, „Sprawozdania Towarzystwa Naukowego KUL" 1971, 20, s. 69-72.

6 Z. Małecki, Sandomierz w latach 1864-1914, w: Dzieje Sandomierza, t. 3, 1795-1914, red. J.M. Małecki, Warszawa 1993, s. 107. 
Buliński opracowując historię miasta, odnotował tylko, że po kasacie zabudowania klasztorne zostały oddane pod zarząd magistratu, a świątynią miał zarządzać kapłan diecezjalny ${ }^{7}$. Informacje na temat sandomierskich dominikanów biorących udział w powstaniu styczniowym zostały przedstawione $\mathrm{w}$ opracowaniach księdza Jana Wiśniewskiego ${ }^{8}$ oraz księdza biskupa Pawła Kubickiego 9 . Dane te zostały uzupełnione i zweryfikowane przez Ewę Jabłońską-Deptułę i Janinę Gawrysiakową ${ }^{10}$. W starszej publikacji Józef Stanisław Pietrzak nie wymienił żadnego z sandomierskich dominikanów jako uczestników zrywu narodowego. Podał tylko kilka nazwisk zakonników zesłanych w głąb Cesarstwa Rosyjskiego lub zabitych w czasie walk powstańczych ${ }^{11}$. Informacje o planach zabudowań klasztornych przy kościele św. Jakuba oraz majątku w Gołębicach opublikowali w katalogu Jerzy Z. Pająk oraz Jerzy Szczepański ${ }^{12}$.

Celem artykułu jest omówienie przebiegu kasaty jednego z najstarszych klasztorów dominikańskich w prowincji polskiej oraz ukazanie jego uposażenia, przejętego na rzecz Skarbu Państwa. W tym celu do publikacji został dołączony aneks źródłowy zawierający szczegółowy protokół

7 M. Buliński, Monografija miasta Sandomierza, Warszawa 1879, s. 308: „Po zniesieniu dominikanów w Sandomierzu w roku 1864, gmachy klasztorne oddane zostały magistratowi miejskiemu, a przy kościele ustanowiony został ksiądz świecki jako kapelan z pensyą złotych tysiąc. Na przebudowanie mieszkania dla tegoż kapłana, oraz dla zrobienia najgłówniejszej restauracyi w kościele, to jest naprawy dachu, rząd przeznaczył przeszło sześć tysięcy złotych".

8 J. Wiśniewski, Udział księży z diecezji sandomierskiej w Powstaniu Styczniowym 1863, Radom 1926, s. 15, 31-32.

9 P. Kubicki, Bojownicy kapłani za sprawe Kościoła i ojczyzny w latach 1861-1915. Materjały $z$ urzędowych świadectw władz rosyjskich, archiwów konsystorskich, zakonnych i prywatnych, cz. 1, Dawne Królestwo Polskie, t. 3, Diecezje: sandomierska, sejneńska, warszawska, emigracja kleru po r. 1863, zakony, zestawienia i spisy, Sandomierz 1933, s. 641, 653, 655, 658.

10 E. Jabłońska-Deptuła, J. Gawrysiakowa, Materiały do zaangażowania patriotycznego zakonów męskich w Królestwie Polskim w latach 1861-1864, w: Materiaty do historii zgromadzeń zakonnych na ziemiach polskich w XIX i na poczatku XX wieku, oprac. H. Dylaggowa et al., Lublin 1976 [Materiały do Atlasu Historycznego Chrześcijaństwa w Polsce, t. 2, cz. 1], s. 51-198. Sytuacja konwentu sandomierskiego przed wybuchem powstania styczniowego została omówiona w artykule D. Burdzy, "O wypadkach zaszłych w mieście Sandomierzu”. Dominikanie z klasztoru przy kościele św. Jakuba w przededniu powstania styczniowego, w: Historia magistra vitae est... Studia z dziejów społeczno-politycznych, gospodarczych i kulturalnych. Księga jubileuszowa dedykowana prof. zw. dr. hab. Wiesławowi Cabanowi z okazji 45-lecia pracy naukowej, red. L. Michalska-Bracha, M. Przeniosło, B. Wojciechowska, Kielce 2016, s. 139-150.

11 J.S. Pietrzak, Księża-powstańcy 1863, Kraków 1913, s. 8-9.

12 Katalog XIX-wiecznych map, planów i rysunków skasowanych klasztorów i ich majątków na terenie guberni kieleckiej i radomskiej, oprac. J.Z. Pająk, J. Szczepański, Kielce 2019, s. 159-190, 236. 
z przejęcia majątku klasztoru dominikanów sandomierskich z 1865 r., który został sporządzony przez asesora ekonomicznego powiatu sandomierskiego Antoniego Jurkowskiego. Podstawę źródłową dla opracowania tej problematyki stanowią materiały przechowywane w Archiwum Państwowym w Radomiu ${ }^{13}$, w Archiwum Diecezjalnym w Sandomierzu ${ }^{14}$ oraz Księga arcybractwa różańcowego, przechowywana w klasztorze przy kościele św. Jakuba ${ }^{15}$. Do przygotowania biogramów zakonników wykorzystane zostały również drukowane katalogi zawierające skład personalny poszczególnych konwentów dominikańskich ${ }^{16}$, jednak dane w nich zawarte (zwłaszcza daty urodzin czy złożenia profesji) należy traktować z ostrożnością, gdyż nie są pozbawione błędów. W celu ich

13 Archiwum Państwowe w Radomiu [dalej: APR], Zarząd Rolnictwa i Dóbr Państwowych Guberni Radomskiej, Kieleckiej, Lubelskiej, Siedleckiej [dalej: ZDP], Sukcesje, sygn. 9601; sygn. 9602; ZDP, Izba Skarbowa Radomska [dalej: ISR], sygn. 281; ZDP, Wydział Gospodarczy gr. II [dalej: WG gr. II], sygn. 665; Rząd Gubernialny Radomski [dalej: RGR], sygn. 4264; sygn. 4265; sygn. 5040.

14 W Archiwum Diecezjalnym w Sandomierzu [dalej: ADS] akta nie posiadają sygnatur tylko tytuły, a także w wielu przypadkach nie są paginowane. Dlatego zamiast stron podawane są daty wystawienia dokumentów. Wykorzystano materiały: Dominikanie Klimontów 1844-1871, [brak sygn.], nlb.; Dominikanie Sandomierz 1845-1867, [brak sygn.], nlb.; Akta Konsystorza Jeneralnego Dyecezyi Sandomierskiej ts. stanu wojennego [dalej: AK], [brak sygn.]. W zakładce dopiętej do tego poszytu wpisano tytuł: „Akta stanu wojny 1861-1865".

15 Archiwum kościoła św. Jakuba w Sandomierzu [dalej: AKSJ], Książka Różańca Ś. Przy kościele ś. Jakuba w Sandomierzu [dalej: Książka], [brak sygn.].

16 Catalogus Conventuum juxta Ordinem Antiquitatis, cum Specifica expressione Religiosorum ac Monialium, Provinciae Polonae S. Ordinis Praedicatorum in Annum 1847, [b.d.m.w.], nlb.; Catalogus Conventuum juxta Ordinem Antiquitatis, cum Specifica expressione Religiosorum ac Monialium, Provinciae Polonae S. Ordinis Praedicatorum in Annum 1851, [b.d.m.w.], nlb.; Catalogus cum specifica expressione Religiosorum ac Monialium Provinciae Polonae S. Hyacinthi Ordinis Praedicatorum, in Annum 1837, [b.d.m.w.], nlb.; Catalogus Patrum et Fratrum ac Monialium Sacri Ordinis Praedicatorum Provinciae Poloniae in annum 1859 conscriptus, [b.d.m.w.], nlb.; Directorium Officii Divini juxta rubricas breviarii ritumque missalis Sacri Ordinis Praedicatorum pro Polona Provincia S. Hyacinthi C.P.R.P. in annum Domini MDCCCLXI, Varsaviae 1861; Directorium Officii Divini juxta rubricas breviarii ritumque missalis Sacri Ordinis Praedicatorum pro Polona Provincia S. Hyacinthi C.P.R.P. in annum Domini MDCCCLXII, Varsaviae 1862; Directorium Officii Divini juxta rubricas breviarii ritumque missalis Sacri Ordinis Praedicatorum pro Polona Provincia S. Hyacinthi C.P.R.P. in annum Domini 1869, [b.m.d.w.]; Schematismus Patrum et Fratrum bec non Monialium S. Ordinis Praedicatorum provinciae St. Hyacinthi, in regno Galiciae austriacae et M.D. Cracoviensi pro anno 1875, Cracoviae 1875. O specyfice tych źródeł zob. Ł. Krucki, Katalog rubrycel i schematyzmów zakonów oraz zgromadzeń zakonnych przechowywanych w ksieggozbiorze podręcznym Archiwum Archidiecezjalnego w Gnieźnie (1767-2008), „Hereditas Monasteriorum” 2015, 6, s. 345-355. 
weryfikacji wykorzystano listy zakonników przesyłane przez przeorów poszczególnych konwentów władzy diecezjalnej i zaborczej, w których wpisywano dokładne daty i miejsca urodzin, a nawet dołączano odpisy aktów urodzenia.

Po upadku powstania styczniowego car Aleksander II Romanow podpisał 8 listopada 1864 r. ukaz likwidacyjny dotyczący cofnięcia wszystkich dotychczas wydanych rozporządzeń w sprawie klasztorów. Tym samym wprowadził ustawę kasacyjną wraz z aktami wykonawczymi, w myśl których podzielono klasztory męskie i żeńskie na dwie kategorie. Pierwsza obejmowała klasztory przeznaczone do „zniesienia”, które liczyły mniej niż osiem osób, ponieważ - zdaniem władz rosyjskich - były one „pozbawione środków do utrzymania porządku i karności”. W wykazach zniesionych klasztorów umieszczono 71 męskich oraz 5 żeńskich. W drugiej kategorii znalazły się klasztory przeznaczone do „zamknięcia” za jawne popieranie powstańców styczniowych. Było to 39 klasztorów męskich, które oskarżono o ,jawny i udowodniony udział w buntowniczych działaniach przeciwko rządowi”. Klasztory „zniesione” podzielono na etatowe i nieetatowe. Te ostatnie zostały objęte zakazem prowadzenia nowicjatu, a tym samym skazane na wymieranie, miały ulec zniesieniu po zmniejszeniu się stanu osobowego poniżej ośmiu. Z kolei klasztory etatowe mogły nadal funkcjonować pod warunkiem nieprzekraczania stanu 14 osób (wyjątkiem Jasna Góra z limitem 24 zakonników) i aż do śmierci ostatniego zakonnika. Do grupy tej zaliczono 25 klasztorów męskich i 10 żeńskich. Na każdy z nich władze przeznaczyły roczną pensję w wysokości 1750 rb., która jednak nie gwarantowała bezpieczeństwa finansowego, tym bardziej że zakazano zakonnikom kwestowania, roznoszenia opłatków i zbierania dziesięciny. Na klasztory etatowe dominikanów ustanowiono Gidle, Klimontów, Lublin i Wysokie Koło ${ }^{17}$. Klasztor przy kościele św. Jakuba w Sandomierzu został zakwalifikowany do grupy klasztorów „zniesionych”, a zakonnicy zostali przeniesieni do klasztoru etatowego w Klimontowie.

Kasata sandomierskiego klasztoru nastąpiła 8 listopada 1864 r. według odgórnie ustalonego schematu, dzięki czemu władze chciały uzyskać pełne zaskoczenie. Niestety nie podano godziny rozpoczęcia kasaty, jednak można przypuszczać per analogiam, że było to w godzinach wieczornych. Namiestnik Królestwa Polskiego hrabia Teodor Berg powierzył wykonanie kasaty klasztorów generałowi-policmajstrowi Teodorowi Trepowowi

17 P.P. Gach, Kasaty, s. 179-180; C. Jastrzębski, Kasata klasztorów w Królestwie Polskim w 1864 r., w: Kasaty klasztorów na obszarze dawnej Rzeczypospolitej Obojga Narodów i na Ślasku na tle procesów sekularyzacyjnych w Europie, t. 1, Geneza. Kasaty na ziemiach zaborów austriackiego i rosyjskiego, red. M. Derwich, Wrocław 2014, s. 356-358. 
oraz cywilnym i wojskowym władzom powiatowym. W procedurach związanych z przejmowaniem majątków poszczególnych zakonów mieli uczestniczyć przedstawiciele duchowieństwa diecezjalnego wyznaczeni przez biskupów. Do przejęcia klasztoru i majątku sandomierskich dominikanów został wydelegowany ze strony Skarbu Królestwa Antoni Jurkowski ${ }^{18}$, asesor ekonomiczny biurowy przy Rządzie Gubernialnym Radomskim, zaś ze strony administracyjnej wyznaczony został przez naczelnika powiatu sandomierskiego Onufry Milczarski prezydent miasta Sandomierza ${ }^{19}$. Delegowani wykonali powierzone im zadanie w obecności delegata ze strony naczelnika wojennego powiatu sandomierskiego, zaś ze strony duchowieństwa - księdza Saturnina Goltza ${ }^{20}$, dziekana sandomierskiego, który w czasie powstania aktywnie działał w konspiracji. Przy czynnościach związanych z kasatą obecny był także przeor skasowanej placówki Paulin Machnicki ${ }^{21}$.

\footnotetext{
18 E. Orzechowska, Własność, s. 193.

19 Onufry Milczarski z Opoczna (1807 - 6 VI 1871), prezydent miasta Sandomierza w latach 1863-1871. Został wybrany na urząd 22 VII 1863 r. przy aprobacie władz carskich. Kontrkandydatem na to stanowisko był Cyprian Strużyński. Do uczestniczenia w przejmowaniu majątku został delegowany w oparciu o pismo naczelnika powiatu sandomierskiego z 25 I 1865 r., E. Orzechowska, Własność, s. 194.

20 Saturnin Goltz - kanonik sandomierski, proboszcz iłżecki, regens konsystorza. Był jednym z trzech księży wysłanych przez duchowieństwo sandomierskie do Komitetu Centralnego powstańczego po wydaniu przez niego odezwy 1 IX 1862 r. Po zapoznaniu się z celami powstańców trzej wysłannicy oświadczyli pozostałym duchownym, że nie pozostaje im nic innego jak tylko poprzeć powstanie, J. Wiśniewski, Katalog pratatów i kanoników sandomierskich od 1186-1926 r. tudzież sesje kapituty sandomierskiej od 1581 do 1866 r., Radom 1926, s. 74-75.
}

21 Paulin Machnicki według katalogu osobowego konwentów z 1847, 1851, 1853, 1859, 1861 urodził się w 1820 r., natomiast na liście zakonników sandomierskiego klasztoru z sierpnia 1864 r. odnotowano, że urodził się 27 II 1821 r. w Urzędowie w Guberni Lubelskiej i tę datę należy uznać za pewną; wstąpił do konwentu lubelskiego i w 1842 r. złożył profesję. Natomiast według katalogu z 1869 r. profesję złożył w 1840 r. Z kolei P. Kubicki (op. cit., s. 655) wymienił go jako Pawła Machnickiego i podał rok 1821 jako datę jego urodzin. Zapewne w oparciu o tę publikację taką samą datę podały E. Jabłońska-Deptuła, J. Gawrysiakowa (op. cit., s. 117-118). Zanim przybył do sandomierskiego klasztoru, pełnił funkcję kaznodziei w konwencie w Janowie Podlaskim (1851 r.), w Janowie Lubelskim (1853 r.) w Wysokim Kole (1859-1861). E. Jabłońska-Deptuła, J. Gawrysiakowa twierdzą, że przeorem w Sandomierzu był od 1863 r., zaś w źródłach poświadczone jest pełnienie przez niego tej funkcji już od $1861 \mathrm{r}$. W listopadzie tego roku zapewniał władze rosyjskie, że w klasztorze przy kościele św. Jakuba nie przechowywano powstańczych mundurów. Brał udział w agitacji narodowej, za co został aresztowany 16 I 1862 r. i osadzony w więzieniu w Radomiu. Ksiądz Jan Wiśniewski podaje, że został oskarżony o udział w pogrzebie Jana Drejzelta 2 XI 1861 r., chociaż tłumaczył się, że tam nie był. Naczelnik wojenny okręgu radomskiego otrzymał polecenie zesłania Machnickiego w głąb Rosji, jednak dzięki wstawiennictwu biskupa sandomierskiego 


\section{W KLIMONTOWIE}

Zakonnicy zostali przeniesieni do klasztoru etatowego w Klimontowie. Zapewne tak jak to było w innych miastach, tak i w tym przypadku przewieziono ich jeszcze tej samej nocy na furmankach i pod konwojem wojskowym w obawie przed reakcją mieszkańców. Udało się uzyskać efekt zaskoczenia, o czym pisał w liście przeor Paulin Machnicki, przebywając już w klasztorze klimontowskim: „,[...] zabrali nas gwałtownie i nadspodziewanie z Sandomierza do Klimontowa ogołoconych ze wszystkiego zawieźli [...]. Ja nie spodziewając się tak nagłego zajęcia klasztoru nic ze zboża nie uprzedałem, $\mathrm{z}$ tego powodu tak mię zastali że zaledwie r[ubli] 4 miałem przy sobie" ${ }^{22}$. Klasztor etatowy, tak jak inne na terenie diecezji, został poddany władzy biskupa sandomierskiego Józefa Michała Juszyńskiego. Do kontroli życia zakonników, finansów i działalności duszpasterskiej poszczególnych domów zakonnych, a także do pośredniczenia w sprawach między władzami diecezjalnymi oraz cywilnymi został wyznaczony przez biskupa sandomierskiego proboszcz Klimontowa Jan Krupiński²3.

W sandomierskim klasztorze pozostawiono ojca Tymoteusza Jaskulskiego ${ }^{24}$, dotychczasowego subprzeora, natomiast w Klimontowie zna-

J.M. Juszyńskiego cofnięto ten wyrok. Wrócił z więzienia do klasztoru w Sandomierzu, ale otrzymał dozór policyjny. W 1869 r. przebywał w klasztorze w Klimontowie jako kaznodzieja, ADS, Dominikanie Sandomierz 1845-1867, [brak sygn.], nlb., Lista zakonników z 4 VIII 1864 r.; AK, [brak sygn.]; Dominikanie Klimontów 1844-1871, [brak sygn.], nlb.; Catalogus 1847, nlb.; Catalogus 1851, nlb.; Catalogus 1837, nlb.; Catalogus 1859, s. 72; Directorium 1861, s. 63; Directorium 1862, s. 53; Directorium 1869, s. 54; J. Wiśniewski, Udziat, s. 15; A. Patkowski, Miłość, równość, braterstwo Polaków w Sandomierzu wobec powstania styczniowego, "Ziemia Sandomierska" 1930, 2, 9, s. 4; E. Orzechowska, Duchowieństwo diecezji sandomierskiej w prowincjonalnej, s. 166-167; idem, Duchowieństwo diecezji sandomierskiej po wprowadzeniu, s. 424; D. Burdzy, "O wypadkach", s. 140, 145-150.

22 ADS, Dominikanie Klimontów 1844-1871, [brak sygn.], nlb., List do księdza Kazimierza Dobrowolskiego, prałata kapituły katedralnej podlaskiej z 10 marca 1865 r. dotyczący jednego z księży demerytów, przebywającego w klasztorze sandomierskim przed kasatą.

23 Jan Krupiński, kanonik kapituły sandomierskiej, gruntownie wykształcony, wykładał Pismo Święte w Akademii Warszawskiej, studiował języki oryginalne Biblii. W 1845 r. został pozbawiony katedry profesorskiej za korespondowanie z hrabiną Marią Ledóchowska, wrócił do diecezji sandomierskiej i otrzymał nadzór policyjny; wykładał w seminarium diecezjalnym. Nie poparł powstania styczniowego, z powodu czego wiele wycierpiat i musiał schronić się w Klimontowie. W 1865 r. otrzymał stanowisko wizytatora klasztorów diecezji sandomierskiej, sprawując je aż do swojej śmierci w 1874 r., J. Wiśniewski, Katalog, s. 165-168.

24 Tymoteusz Jaskulski (ur. 30 XI 1818 r. w Wieluniu w województwie kaliskim), w latach 1847-1853 przebywał w klasztorze warszawskim, gdzie w 1850 r. złożył profesję zakonną. W 1859 r. pełnił funkcję hebdomadariusza w klasztorze lubelskim, zaś w latach 
leźli się: wspomniany już przeor Paulin Machnicki, Alfons Koliński ${ }^{25}$, Hilary Sobolewski ${ }^{26}$, Ewaryst Rutkowski ${ }^{27}$ i Kajetan Kwitek ${ }^{28}$. W księ-

1861-1862 był kapelanem w klasztorze w Wysokim Kole. Jako wikariusz kościoła św. Jakuba po kasacie pozostał w sandomierskim klasztorze do 1870 r., został przeniesiony do Klimontowa, skąd wkrótce przeniósł się za granicę, jednak brak informacji, aby miejscem docelowym był któryś z konwentów dominikańskich. Schematyzm klasztorów dominikańskich w Galicji z 1875 r. nie wymienia jego nazwiska, ADS, Dominikanie Sandomierz 1845-1867, [brak sygn.], nlb., Lista zakonników z 4 VIII 1864 r.; Dominikanie Klimontów 1844-1871, [brak sygn.], nlb.; Directorium 1859, s. 69; Directorium 1861, s. 63; Directorium 1862, s. 55; Directorium 1869, s. 54-56; Schematismus 1875.

25 Alfons (Józef Stanisław) Koliński (ur. 6 lub 9 V 1824 r. we wsi Stanisławów w guberni grodzieńskiej) profesję zakonną złożył w $1844 \mathrm{r}$. w klasztorze warszawskim, tam też w 1847 r. został wymieniony jako kleryk Św. Teologii. W 1851 r. pełnił funkcję hebdomadariusza w klasztorze w Sochaczewie, zaś dwa lata później ponownie znalazł się w Warszawie, w 1859 r. był kaznodzieją w Janowie Podlaskim, a w 1861 r. w tej samej roli przebywał ponownie w Sochaczewie. W katalogu za 1862 r. został wymieniony jeszcze jako promotor Różańca Św. w klasztorze w Sieradzu. Do klasztoru sandomierskiego przybył dopiero 10 VI 1864 r., ADS, Dominikanie Sandomierz 1845-1867, [brak sygn.], nlb., Lista zakonników z 4 VIII 1864 r.; Dominikanie Klimontów 1844-1871, [brak sygn.], nlb.; Directorium 1847, nlb.; Directorium 1851, nlb.; Directorium 1853, nlb.; Directorium 1859, s. 68; Directorium 1861, s. 61; Directorium 1862, s. 53; Directorium 1869, s. 54.

26 Hilary Sobolewski (ur. 21 XI 1839 r. w Tarnogrodzie w guberni radomskiej) do zakonu wstąpił w 1859 r. w Warszawie, profesję złożył w 1860 r. Po kasacie sandomierskiego klasztoru pełnił funkcję przełożonego w klasztorze etatowym w Klimontowie, w $1871 \mathrm{r}$. uzyskał zwolnienie z tych obowiązków i wyjechał do archidiecezji warszawskiej, ADS, Dominikanie Sandomierz 1845-1867, [brak sygn.], nlb., Lista zakonników z 4 VIII 1864 r.; Dominikanie Klimontów 1844-1871, [brak sygn.], nlb.; Directorium 1862, s. 62 podaje datę 1838 r. jako datę urodzin.

27 Ewaryst (Michał) Rutkowski (ur. 8 IX 1838 r. we wsi Sitaniec w guberni lubelskiej - zm. w 1914 r.) profesję zakonną złożył w 1858 r. W czasie powstania jako kleryk samodzielnie opuścił klasztor lubelski. Z 20 VII 1864 r. pochodzi pierwsza wzmianka o jego pobycie w klasztorze sandomierskim (określono go diakonem), z którego po kasacie został przeniesiony do Klimontowa. Święcenia kapłańskie przyjął w 1867 r. Dwa lata później w tym klasztorze pełnił obowiązki kaznodziei, zaś w 1870 r. opuścił klasztor i przeniósł się do diecezji lubelskiej, ADS, Dominikanie Sandomierz 1845-1867, [brak sygn.], nlb., Lista zakonników z 4 VIII 1864 r.; Dominikanie Klimontów 1844-1871, [brak sygn.], nlb.; Directorium 1859, s. 69; Directorium 1861, s. 60; Directorium 1862, s. 52 Directorium 1869, s. 54; P. Kubicki, op. cit., s. 658; D. Burdzy, „O wypadkach”, s. 149. Według E. Jabłońskiej-Deptuły, J. Gawrysiakowej, op. cit., s. 120, do zakonu wstąpił w 1855 r., a po kasacie pracował jako proboszcz w parafii Wereszyn, co jest sprzeczne z informacjami podanymi w Directorium z 1869 r.; E. Niebelski, Nieprzejednani wrogowie, s. 231, podaje w wątpliwość jego udział w powstaniu.

28 Kajetan (Andrzej) Kwitek (ur. 3 XI 1842 r. w Wysokiem w guberni lubelskiej - zm. w 1923 r.) do zakonu wstąpił w 1858 r. w klasztorze w Wysokim Kole, a profesję zakonną złożył w 1859 r. W latach 1861-1863 był klerykiem w klasztorze lubelskim, który samodzielnie 
dze arcybractwa różańcowego przy kościele św. Jakuba odnotowano, że w czasie kasaty w sandomierskim klasztorze przebywało tylko czterech zakonników ${ }^{29}$, prawdopodobnie nie wzięto pod uwagę diakona Rutkowskiego i kleryka Kwitka, natomiast doliczono Romana Cieślickiego ${ }^{30}$, który w czasie powstania pełnił obowiązki duchownego w parafii w Tarłowie i został zatrzymany przez komisję śledczą w Radomiu. Następnie został odesłany do klasztoru w Janowie Lubelskim, gdzie zastał go ukaz kasacyjny i wraz z tamtejszymi zakonnikami przybył do Klimontowa. Informacje te weryfikuje szczegółowa lista zakonników z klasztoru etatowego w Klimontowie, którą przygotowano 26 grudnia 1864 r. już po przybyciu do niego zakonników z Sandomierza oraz z Janowa Lubelskiego (Ordynackiego) i Krasnobrodu ${ }^{31}$.

opuścił i przyłączył się do powstania. Najpierw walczył w partii Henryka Granowskiego, brał udział w potyczkach pod Tomaszowem Lubelskim (1 i 5 II 1863 r.), następnie znalazł się w partii Marcina Borelowskiego-Lelewela. Po raz pierwszy w składzie sandomierskiego konwentu (jako kleryk profes) został wymieniony 20 VII 1864 r. razem z E. Rutkowskim i przeorem P. Machnickim. Po kasacie sekularyzował się i pracował jako kapłan w diecezji sandomierskiej, w 1872 r. otrzymał probostwo w Samborcu, gdzie też zmarł. Był także kanonikiem honorowym kapituły kaliskiej, ADS, Dominikanie Sandomierz 1845-1867, [brak sygn.], nlb., Lista zakonników z 4 VIII 1864 r.; Ks. Kajetan Kwitek 1867-1922; Dominikanie Klimontów 1844-1871, [brak sygn.], nlb.; Directorium 1861, s. 60; Directorium 1862, s. 52; J. Wiśniewski, Udział, s. 31-32; P. Kubicki, op. cit., s. 633; E. Jabłońska-Deptuła, J. Gawrysiakowa, op. cit., s. 117; J. Kowalczyk, Inwentaryzacja miejsc pamięci powstania styczniowego na terenie województwa świętokrzyskiego (opis obiektów), w: J. Kowalczyk, A. Massalski, T. Wagrowski, Whołdzie przeszłości 1863-1864. Województwo świętokrzyskie, Kielce 2003, s. 145; E. Niebelski, Nieprzejednani, s. 231-232; B. Stanaszek, Duchowieństwo diecezji sandomierskiej w latach 19181939, Lublin 1999, s. 154, 428; D. Burdzy, "O wypadkach”, s. 149.

29 AKSJ, Książka, s. 267.

30 Roman Cieślicki (ur. 1 X 1836 r. w Urzędowie w województwie lubelskim) od grudnia 1863 r. przebywał na parafii w Tarłowie, pełniąc obowiązki wikariusza. Odnotowano, że: „przed rokiem w Sandomierzu zamieszkały, a później przez zbieg okoliczności aresztowany przez władze wojskowe w Radomiu, i po wytłomaczeniu się uwolniony - $\mathrm{z}$ chęcią zastępstwa obowiązki wikariusza w Tarłowie tymczasowo zobowiązał się wykonywać", na co otrzymał zgodę. W lipcu 1863 r. został zatrzymany do dyspozycji komisji śledczej w Radomiu, prawdopodobnie za samowolne opuszczenie Sandomierza bez wymaganego paszportu, ADS, Dominikanie Sandomierz 1845-1867, [brak sygn.], nlb., Lista zakonników z 4 VIII 1864 r.; Dominikanie Klimontów 1844-1871, [brak sygn.], nlb.; P. Kubicki, op. cit., s. 641; E. Orzechowska, Aresztowania, s. 213, 225; E. Jabłońska-Deptuła, J. Gawrysiakowa, op. cit., s. 116.

31 ADS, Dominikanie Klimontów 1844-1871, [brak sygn.], nlb., Lista imienna osób zakonnych znajdujących się w klasztorze oo. dominikanów w klasztorze klimontowskim sporządzona 26 XII 1864 r. Bardziej szczegółową listę zakonników przygotowano 24 I 1865 r., podając dodatkowo miejsce urodzenia, a także nazwę parafii, gdzie część dominikanów 
W tabeli 1 zamieszczono imię i nazwisko zakonnika, urząd pełniony $\mathrm{w}$ zakonie, datę urodzenia i informację, czy był on kapłanem lub profesem oraz inne uwagi. Według tego spisu do ośmiu dominikanów klimontowskich i jednego kapłana diecezjalnego (emeryta) oraz demeryta dołączyło pięciu zakonników z Sandomierza i demeryt (kapłan diecezjalny), pięciu dominikanów z Janowa Lubelskiego oraz dwóch z Krasnobrodu. Z analizy danych wynika, że w klasztorze etatowym przebywało dwudziestu zakonników, w tym czterech przeorów (jeden urzędujący i trzech byłych) oraz trzech księży świeckich. Na listach z kolejnych lat wymieniano już samych zakonników, ponieważ to oni byli upoważnieni do otrzymywania etatu. Kiedy w 1866 r. z kasy powiatowej wypłacano klasztorom etatowym diecezji sandomierskiej należne kwoty za pierwszy tercjał (cztery miesiące), na liście wymieniono już tylko osiemnastu zakonników w Klimontowie, wśród których czternastu było określanych jako „etatowi” i należało im wypłacić 583,33 rb., zaś czterem „nadkompletnym" przypadło 53,33 rb. ${ }^{32}$ Tak więc kwota przeznaczona do wypłaty dla dominikanów ,etatowych" wynosiła tyle ile wyznaczono dla każdego klasztoru w ukazie kasacyjnym (1750 rb. rocznie). Niestety nie sprecyzowano, czy wszyscy zakonnicy w Klimontowie otrzymywali jednakową sumę. Gdyby jednak przyjąć taką zasadę podziału, wówczas na każdego $\mathrm{z}$ nich przypadałoby po $125 \mathrm{rb}$. rocznie (10,42 rb. miesięcznie). Jeszcze mniej otrzymywali zakonnicy "nadkompletni” - po $40 \mathrm{rb}$. rocznie $(3,33 \mathrm{rb}$. na miesiąc). Były to głodowe stawki, niewystarczające do przeżycia nawet w skromnych warunkach.

Jednak realia życia w klasztorze daleko odbiegały od tych przedstawionych na papierze, zwłaszcza jeśli chodzi o terminowe wypłacanie pensji i zaspokajanie potrzeb wszystkich zakonników. Żalił się na ten stan Paulin Machnicki we wspomnianej korespondencji, opisując, że zawieźli ich do Klimontowa „,...] nie tylko z Sandomierza, ale z Krasnobrodu i Janowa Ordynackiego, razem nas tu zgromadzili, mieszkamy przeszło 3 miesiące a żadnej pensyi na nas nie przeznaczają. Nie wyobrazi sobie

pełniła obowiązki wikariuszy. Przy pozostałych zaś odnotowano, że przebywają w klasztorze, pełniąc funkcje we władzach lub jako emeryci. Ibidem, Lista zakonników zgromadzenia ks. ks. dominikanów znajdujących się obecnie w klasztorze klimontowskim w powiecie sandomierskim ułożona 24 I 1865 r.

32 APR, RGR, sygn. 4265, s. 29-30: „Licząc w stosunku summy r[ubli] 1750 etatem oznaczonej przypada dla 14 zakonników r[ubli] 583 k[opiejek] 33. Nadto dodając dla 4 zakonników nadkompletnych w stosunku rocznym r[ubli] 40 dla każdego [rubli] 53 k[opiejek] 33. Przypada do wypłaty w ogóle r[ubli] 633 k[opiejek] 66". Łączna kwota do wypłaty W rzeczywistości wynosiła 636,66 rubla, s. 7, 11. W 1865 r. klasztor miał otrzymać 596,66 rb. (APR, RGR, sygn. 4264, s. 146). W grudniu 1865 r. podano, że klasztor ten powinien mieć wypłacone 5,84 rb. Ibidem, s. 204. 

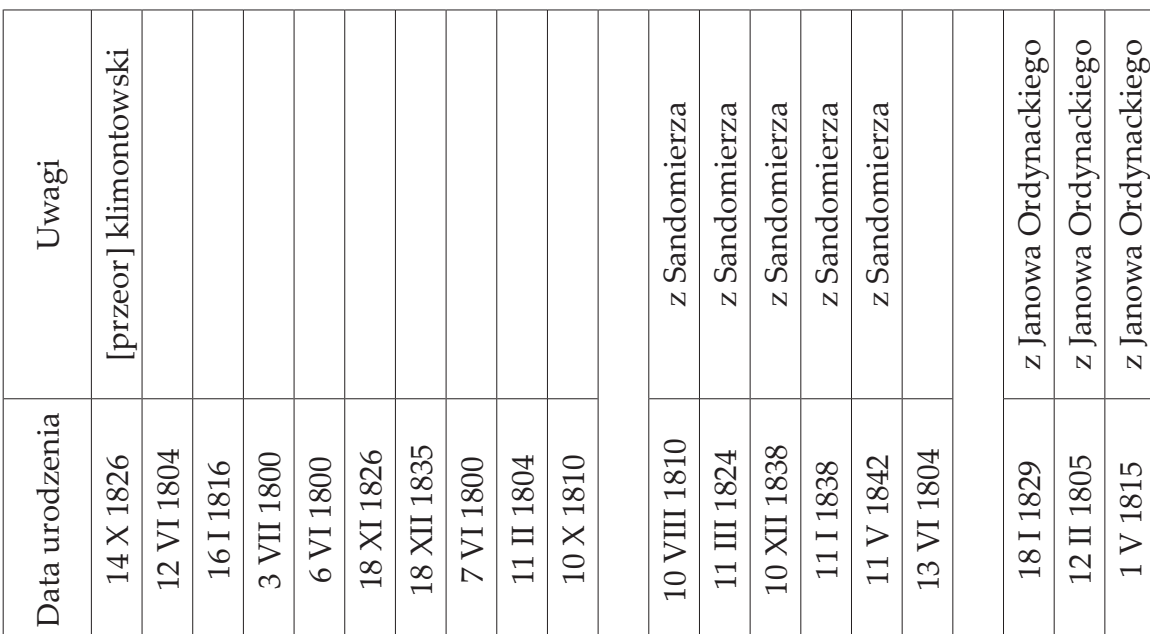

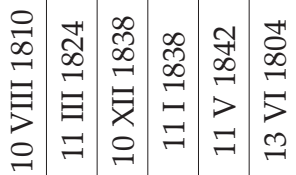

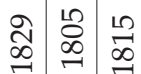

$\underset{\infty}{\sim} \rightleftharpoons$

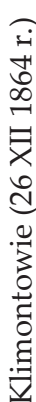

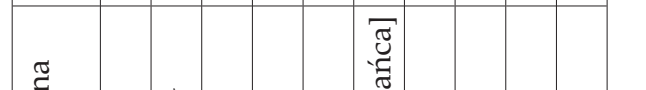

$\infty$

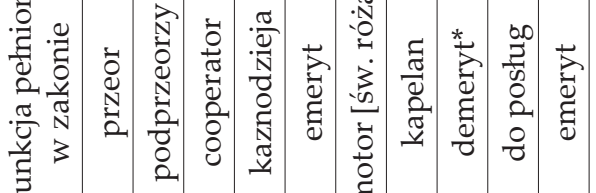

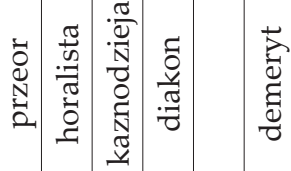

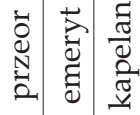

展

3

3. तुํํำ

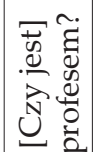

ڤัٌ

胥

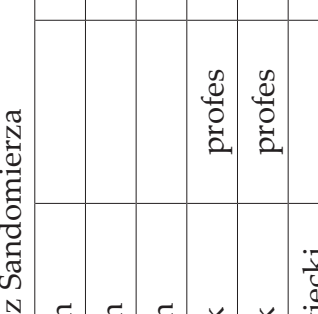

हुँ

䓎

竧

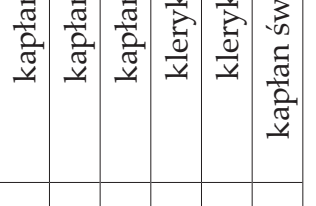

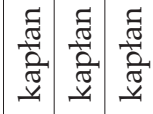

亲

交

离

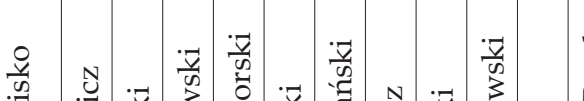

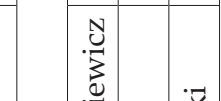

西

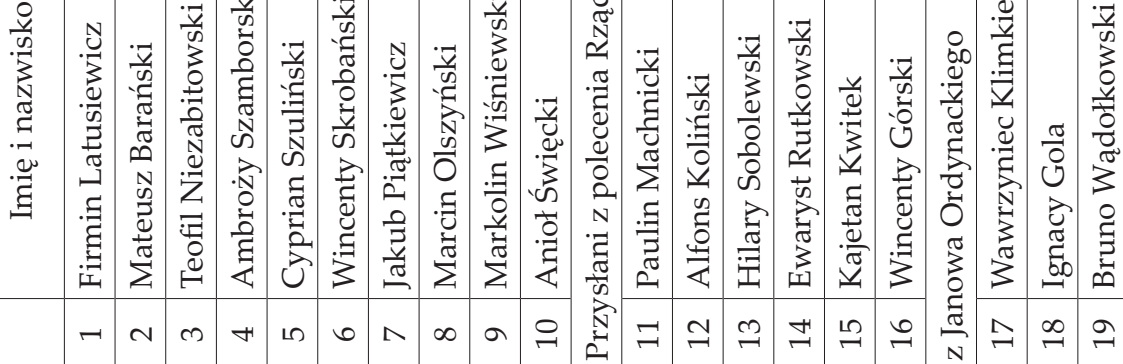




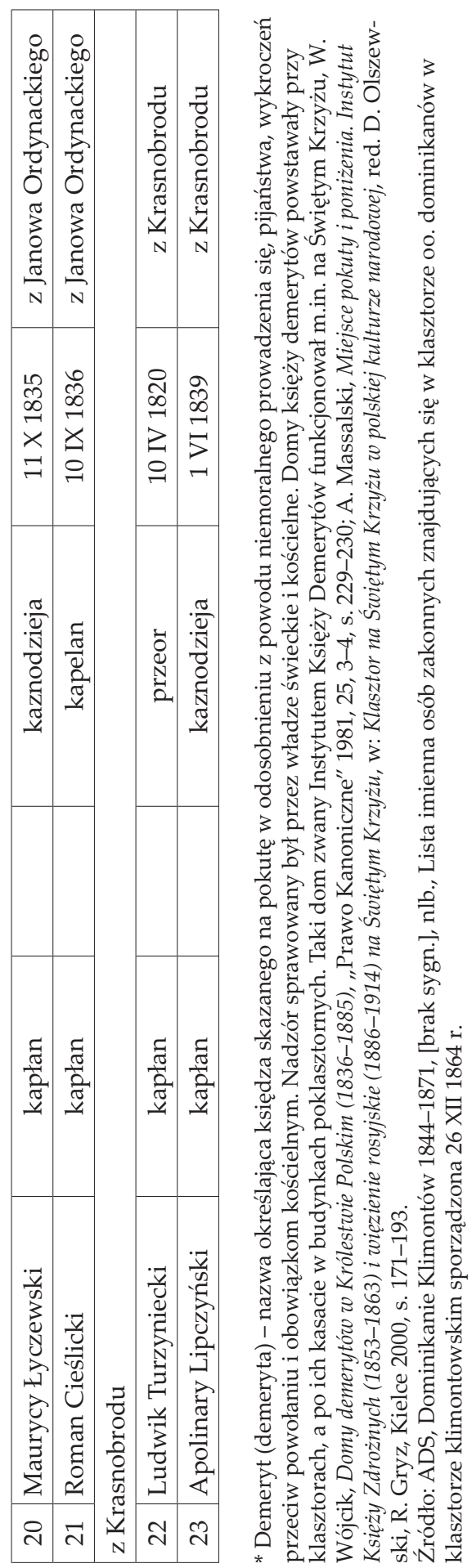


Ksiądz Prałat Dobrodziej jaka nędza, głód i niedostatek nas dotknął"33. W kolejnym liście relacjonował: „W wielkiej nędzy i potrzebie jesteśmy, ta należytość [300 rb.] nie tylko na mnie przypada, ale i na innych braci, a szczególniej kleryków, dotychczas ich trzymają i żadnego porządku z nimi nie robia, ale nie tylko ich, ale i wszystkich nas a szczególniej przełożonym nigdzie wyjechać nie pozwalają. Mieszka nas 18 należną pensyą z trudnością wypłacają już pół roku upływa a jeszcześmy nie odebrali, a chociaż się i odbierze to idzie do ogólny kassy a na osobę nic, a tu potrzeba [...] na habit, buty, opranie etc. A tu nie ma znikąd żadnych zasiłków, nawet na Mszą św. w tym biednym Klimontowie nikt nie da" ${ }^{\prime 3}$. Lakoniczne przedstawienie w liście złej sytuacji kleryków dominikańskich w rzeczywistości odnosiło się do ich wielokrotnie podejmowanych starań o zgodę na kontynuowanie nauki w Seminarium Diecezjalnym w Sandomierzu (Kajetan Kwitek) lub o otrzymanie święceń kapłańskich (Ewaryst Rutkowski). Kwitek po złożeniu kilku próśb do biskupa za pośrednictwem wizytatora klasztorów, po dołączeniu kilku zaświadczeń o dobrym sprawowaniu i złożeniu przysięgi na wierność carowi otrzymał możliwość przejścia do duchowieństwa diecezjalnego. Rutkowski również kilkakrotnie prosił o możliwość otrzymania święceń, ponieważ przebywając w klasztorze, nie mógł odprawiać mszy, nie mógł też pomagać w parafii. Przed ukazem kasacyjnym złożył śluby zakonne, więc kiedy w 1867 r. został wyświęcony, musiał pozostać w zakonie, tym bardziej że było sześć tysięcy zaległych obligacji mszalnych do odprawienia, które skumulowały się po zniesieniu innych klasztorów w diecezji sandomierskiej. Biskup J.M. Juszyński w opinii wydanej na polecenie Komisji Rządowej Spraw Wewnętrznych i Duchownych (KRSWiD) o tym zakonniku stwierdził, że pozostali księża zakonni nie byli w stanie sami sprostać odprawieniu takiej liczby mszy ${ }^{35}$.

Liczba zakonników w klimontowskim klasztorze z biegiem lat się zmieniała, wykazując tendencję spadkowa ponieważ większość z nich starała się o czasowe przeniesienie na parafie w charakterze wikariuszy lub przeniesienie do duchowieństwa diecezjalnego (sekularyzację) i również pełnienie obowiązków duszpasterskich w parafiach. Nie wszystkim się to udawało, ponieważ przed uzyskaniem pozwolenia od biskupa sandomierskiego (a w przypadku sekularyzacji od Stolicy Apostolskiej ${ }^{36}$ )

33 ADS, Dominikanie Klimontów 1844-1871, [brak sygn.], nlb., List do księdza Kazimierza Dobrowolskiego, prałata kapituły katedralnej podlaskiej z 10 III 1865 r.

34 ADS, Dominikanie Klimontów 1844-1871, [brak sygn.], nlb., List do księdza Kazimierza Dobrowolskiego, prałata kapituły katedralnej podlaskiej z 17 II 1866 r.

35 Ibidem, Pismo biskupa sandomierskiego J.M. Juszyńskiego do KRSWiD z VII 1866 r.

36 Szerzej zob. R. Prejs, Zakonnicy Królestwa Polskiego po kasacie 1864 r. Zagadnienia wybrane, „Nasza Przeszłość” 1997, 88, s. 315-324. 
byli dokładnie sprawdzani przez władze wojskowe „pod względem politycznym", co zapewne odnosiło się do ich zachowania w czasie wydarzeń z okresu 1861-1864. Jeżeli nie cieszyli się zaufaniem władz świeckich, nie uzyskiwali zgody na przejście do diecezji i musieli pozostać w klasztorze. Tak było w przy padku wspomnianego Romana Cieślickiego z sandomierskiego klasztoru czy też Maurycego Łyczewskiego z Janowa Lubelskiego.

Szczegółowej kontroli poddawano także zakonników, którzy mieli objąć funkcję przełożonego, wikariusza i prokuratora w klasztorze. Egzemplifikacją tego jest zmiana władz w 1865 r. W maju dotychczasowy przeor Firmin Latusiewicz opuścił klasztor i przeniósł się na parafię do Olbierzowic. Powołał się na decyzję KRSWiD z 31 października 1864 r., na mocy której został zatwierdzony na proboszcza $w$ tej miejscowości. Jednak ukaz o kasacie klasztorów zastał go jeszcze pełniącego funkcję przełożonego w Klimontowie i z tego powodu nie mógł objąć parafii. Prosił zatem władze wojskowe, aby pozwoliły mu na rezygnację z pełnienia funkcji przeora i udanie się na parafię, ponieważ nie był w stanie pogodzić wszystkich obowiązków: ,"...] parafia wymaga jego bytności jako urzędnika Stanu Cywilnego zwłaszcza w tym czasie, w którym wyciągi z akt urodzonych, zaślubionych i zmarłych do spisu ludności wydawać należy". Na swojego następcę w klasztorze zaproponował Wawrzyńca Klimkowicza ${ }^{37}$. Otrzymał taką zgodę i opuścił Klimontów, a w piśmie skierowanym do konsystorza sandomierskiego poinformował, że scedował obowiązki przełożonego na Hilarego Sobolewskiego ${ }^{38}$. Nie wiadomo, kto ostatecznie przejął jego obowiązki w klasztorze, ponieważ w sierpniu 1865 r. okazało się, że KRSWiD nie zaakceptowała zaproponowanych trzech kandydatów do przejęcia władzy w klasztorze (nie podano ich nazwisk). Z tego powodu Roch Ratuszny, były prowincjał dominikanów, mieszkający w klasztorze w Gidlach, przedstawił kolejnych zakonników, mianowicie na przełożonego Jakuba Piątkiewicza, na wikarego Wincentego Skrobańskiego, a na prokuratora Hilarego Sobolewskiego, przybyłego z klasztoru sandomierskiego. Jednak we wrześniu KRSWiD zdecydowała, że przełożonym zostanie Hilary Sobolewski, zaś wikariuszem - Skrobański, a prokuratorem Piątkiewicz. Wszystkich dokładnie sprawdzono i okazało się, że w opinii władz rosyjskich Piątkiewicz ze Skrobańskim nie odznaczali się przykładnym życiem, jednak nie sprecyzowano

37 ADS, Dominikanie Klimontów 1844-1871, [brak sygn.], nlb., Pismo do KRSWiD o rezygnacji Firmina Latusiewicza z przełożeństwa klasztoru klimontowskiego i zaproponowaniu na zastępcę Wawrzyńca Klimkowicza z 22 V 1865 r.

38 ADS, Dominikanie Klimontów 1844-1871, [brak sygn.], nlb., Raport Firmina Latusiewicza do konsystorza sandomierskiego o złożeniu przełożeństwa na ręce x. Hilarego Sobolewskiego z 14 VI 1865 r. 
o co dokładnie chodziło. Ponadto proponowany na przełożonego Piątkiewicz nie zasługiwał na całkowite zaufanie władz wojskowych i cywilnych. Natomiast w odniesieniu do Sobolewskiego stwierdzono, że jako jedyny w klasztorze był zdolny do rozciągnięcia odpowiedniego nadzoru nad wszystkimi zakonnikami, zwłaszcza nad tymi, którzy byli podejrzani o spiskowanie przeciwko władzom zaborczym ${ }^{39}$. Wkrótce Skrobański i Piątkiewicz powrócili z parafii i objęli swoje urzędy, jednak nie potraktowali tego jako awansu, przeciwnie, oznaczało to dla nich stałe przebywanie w klasztorze i niemożność zdobycia dodatkowych środków jako wikariusze przy kościołach parafialnych. W październiku $1865 \mathrm{r}$. Piątkiewicz poprosił o uwolnienie od obowiązków prokuratora klasztoru, a następnie o sekularyzację, twierdząc, że „za ten mozolny urząd żadnej pensyi nie ma", przez co nie będzie mógł wspierać finansowo swoich rodziców w Opatowie i brata oddanego do szkół na swój koszt. Pomimo tych argumentów władze nie zgodziły się na jego zwolnienie z klasztoru i rezygnację z funkcji prokuratora ${ }^{40}$.

Dla Hilarego Sobolewskiego funkcja przełożonego klasztoru klimontowskiego nie była łatwą do sprawowania, jego młody wiek i brak doświadczenia w zarządzaniu klasztorem, ubóstwo wspólnoty potęgowane przez spóźniające się wypłaty pensji, złe warunki mieszkaniowe, a nawet konflikty między zakonnikami nie poprawiały i tak ciężkiej sytuacji tego klasztoru. Swoją funkcję sprawował do 1871 r., kiedy to wyjednał zgodę na stałe przeniesienie do archidiecezji warszawskiej ${ }^{41}$.

Przy kościele podominikańskim św. Jakuba w Sandomierzu pozostawiono ojca Tymoteusza Jaskulskiego jako wikariusza. W korespondencji diecezjalnej określano go również mianem rektora tej świątyni. Być może wybór ten podyktowany był faktem, że nie brał udziału w wydarzeniach poprzedzających powstanie styczniowe i w samym zrywie, przynajmniej

39 Ibidem, Pismo Rocha Ratusznego do konsystorza sandomierskiego z 2 VIII 1865 r.; Pismo KRSWiD do biskupa sandomierskiego J.M. Juszyńskiego z 9/21 IX 1865 r.; Pismo biskupa sandomierskiego J.M. Juszyńskiego do Dyrektora Głównego KRSWiD z 23 IX 1865 r.; Pismo konsystorza sandomierskiego do klasztoru dominikanów w Klimontowie z 16 X 1865 r.

40 Ibidem, Prośba Jakuba Piątkiewicza do wizytatora klasztorów w diecezji sandomierskiej z 7 X 1865 r.; Pismo Gubernatora Radomskiego do biskupa sandomierskiego J.M. Juszyńskiego z 6 XII 1865 r.; Pismo wizytatora klasztorów diecezji sandomierskiej do konsystorza sandomierskiego z 19/31 XII 1865 r.; Pismo konsystorza sandomierskiego do Jakuba Piątkiewicza z 2 I 1866 r.

41 Ibidem, Pismo Zarządzającego sprawami duchownymi obcych wyznań w Królestwie Polskim do biskupa sandomierskiego J.M. Juszyńskiego z 15/27 II 1871 r.; Pismo przełożonego dominikanów klasztoru klimontowskiego do konsystorza sandomierskiego z 31 III $1871 \mathrm{r}$. 
badacze nie wymieniają go wśród zaangażowanych zakonników. Przebywał on czasowo przy kościele św. Jakuba w celu odprawiania nabożeństw, dopóki biskup nie wyznaczył do pełnienia tych obowiązków księdza diecezjalnego. W 1866 r. Namiestnik Królestwa zabronił, aby na miejsce zmarłych lub przeniesionych zakonników wybierać do obsługi kościołów poklasztornych innych zakonników i zalecił, aby wyznaczać duchownych diecezjalnych ${ }^{42}$. W oparciu o paragraf 18 przepisów dodatkowych do ukazu kasacyjnego z 1864 r. wyznaczono Jaskulskiemu pensję w wysokości 150 rb. rocznie, zaś dla organisty Michała Chołody - 75 rb., a dla zakrystiana Franciszka Sobolewskiego - 60 rb. Rząd Gubernialny zastrzegł jednak, żeby wypłacano te należności wyłącznie osobom, które stale przebywały przy kościołach poklasztornych i wypełniały powierzone im obowiązki ${ }^{43}$. Magistrat Sandomierza uznał za konieczne utrzymanie zakrystianów przy kościele św. Jakuba oraz poreformackim św. Józefa, aby dbali o czystość w świątyni oraz o porządek w paramentach i szatach liturgicznych. Mieli oni usługiwać do mszy św., a w czasie większych nabożeństw i uroczystości powinni pomagać organistom, kalikując na chórze (czyli pompując powietrze do miechów organowych za pomocą dźwigni). $Z$ tego powodu proszono o wypłacenie zakrystianom po $60 \mathrm{rb}$., ponieważ oba kościoły nie miały żadnych innych funduszów ani ofiar i nie byłyby w stanie ich utrzymać. Przez to nie mogłaby być należycie sprawowana służba boża ${ }^{44}$. W lipcu $1865 \mathrm{r}$. KRSWiD postanowiła wypłacić wikariuszom i organistom należność za okres od momentu skasowania klasztoru aż do końca 1864 r., ponieważ wówczas też wypełniali swoje obowiązki. Jaskulski miał otrzymać $13,75 \mathrm{rb}$., a organista $6,875 \mathrm{rb} .{ }^{45}$

Jaskulski był obecny przy przejmowaniu księgozbioru klasztornego na rzecz seminarium diecezjalnego w 1866 r. Na początku 1867 r. był przepytywany na tę okazję przez asesora ekonomicznego okręgu sandomierskiego. Oświadczył wówczas, że biblioteka została w całości zabrana przez kanonika Gackiego, natomiast aparaty i naczynia kościelne znajdujące się w kościele św. Jakuba były te same jak przed kasatą ${ }^{46}$. Opiekował się również arcybractwem różańcowym, wpisując nowo przyjętych członków do księgi brackiej.

\footnotetext{
42 APR, RGR, sygn. 4265, s. 93-94.

43 Ibidem, s. 39, 43, 47. Rząd Gubernialny Radomski polecił Kasie Gubernialnej Radomskiej zapisać wydatki na wikariuszy przy wszystkich skasowanych klasztorach jako czasowe w pozycji „,na utrzymanie wikariuszów i organistów przy kościołach poklasztornych”, s. 48 .

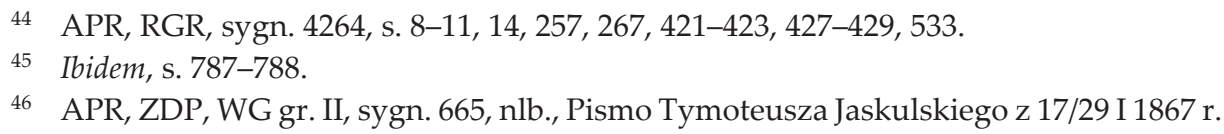


Przebywał przy kościele filialnym św. Jakuba do września 1870 r., kiedy to od naczelnika powiatu otrzymał polecenie przeniesienia się do klasztoru etatowego w Klimontowie. W piśmie skierowanym do konsystorza sandomierskiego polecono, aby dominikanin następnego dnia (30 września 1870 r. o godz. 10.00) stawił się w biurze powiatu sandomierskiego, skąd miał być przewieziony do Klimontowa na stałe przebywanie $^{47}$. W styczniu $1871 \mathrm{r}$. przyznano mu wypłatę $6,35 \mathrm{rb}$. za pełnienie obowiązków wikariusza w Sandomierzu za okres 13-28 września 1870 r. ${ }^{48}$ Natomiast w listopadzie tego roku zdecydował się wyjechać bezpowrotnie za granicę z dożywotnią pensją $150 \mathrm{rb}$. Konsystorz generalny sandomierski przekazał tę informację wizytatorowi klasztorów z poleceniem, aby doręczył decyzję Ministerstwa Spraw Wewnętrznych Jaskulskiemu oraz przełożonemu dominikanów w Klimontowie, zobowiązując tego ostatniego do powiadomienia władzy diecezjalnej o terminie opuszczenia klasztoru przez zakonnika ${ }^{49}$.

\section{ARCYBRACTWO RÓŻAŃCOWE}

Ważną rolę w podtrzymaniu kultu maryjnego i świętych zakonu dominikańskiego odegrało wspomniane arcybractwo różańcowe ${ }^{50}$, które, jak odnotowano w księdze brackiej: „[...] a lubo XX. Dominikanie w r. 1864 od kościoła św. Jakuba suprymowani zostali, arcybractwo jednak pozostało i exystencja jego jako etatowego prawem Rządu uznana"51. Do jego obowiązków należało podtrzymywanie nabożeństwa różańcowego, oświetlanie ołtarzy i wizy towanie chorych. Posiadało własny fundusz, corocznie wypłacany z kasy powiatowej, oraz dochody ze składek od członków i nowo przyjmowanych.

47 ADS, Dominikanie Klimontów 1844-1871, [brak sygn.], nlb., Pismo Zarządu Powiatu sandomierskiego do konsystorza sandomierskiego z 17/29 IX 1870 r.; Pismo konsystorza sandomierskiego do Tymoteusza Jaskulskiego z 18/30 IX 1870 r.

48 Ibidem, Pismo konsystorza sandomierskiego do przełożonego dominikanów z klasztoru klimontowskiego z 28 I/9 II 1871 r.

49 Ibidem, Pismo konsystorza sandomierskiego do przełożonego dominikanów z klasztoru klimontowskiego z 25 X/6 XI $1871 \mathrm{r}$.

50 Szerzej na temat roli bractw religijnych w tym okresie zob.: E. Jabłońska-Deptuła, Dominikańska opozycja. Przyczynek do społecznego charakteru bractw w połowie XIX w., „W Drodze" 1973, 1, 3-4, s. 96-105; eadem, Zakony męskie Królestwa wobec rzeczywistości zaborczej 1815-1864. Kilka problemów badawczych, "Roczniki Humanistyczne” 1974, 22, 2, s. 126; S. Wiech, Rola i udział żandarmerii w walce z Kościołem rzymskokatolickim w Królestwie Polskim w latach 1864-1905, „Kwartalnik Historyczny” 2000, 107, 1, s. 50-52.

51 AKSJ, Książka, s. 233. 
W 1865 r. przedstawiciele władz brackich: Wojciech Gielerak tytułowany przeorem brackim oraz Mateusz Józefowicz pełniący funkcję subprzeora brackiego, zwrócili się do konsystorza diecezji sandomierskiej, aby udzielił im upoważnienia do odbierania pieniędzy z kasy powiatowej. Arcybractwo posiadało w Banku Polskim kapitał 2000 złp ulokowany na procent $\mathrm{w}$ wysokości 80 złp rocznie, który przed kasatą odbierał przełożony klasztoru. Natomiast po ukazie kasacyjnym kasa powiatowa zażądała urzędowego upoważnienia dla osoby, której miałaby wypłacać wspomnianą kwotę. Gielerak i Józefowicz prosili, aby władza diecezjalna przedstawiła rządowi gubernialnemu osobę przez nich zaproponowana, mianowicie wizytatora klasztorów w diecezji sandomierskiej lub zakonnika Jaskulskiego pozostającego przy kościele św. Jakuba bądź też któregoś z członków władz arcybractwa. W odpowiedzi na tę prośbę konsystorz wyznaczył właśnie Gieleraka jako przeora arcybrackiego do odbierania pieniędzy ${ }^{52}$. We wrześniu 1866 r. rząd gubernialny radomski zwrócił się do konsystorza, aby poinformował arcybractwo różańcowe w Sandomierzu o możliwości odebrania zaległej kwoty 12 rb. za 1865 r. z kasy gubernialnej. Informację tę oficjał przesłał na ręce dominikanina Tymoteusza Jaskulskiego, z poleceniem, aby poinformował o tym członków arcybractwa ${ }^{53}$. Prawdopodobnie była to część wspomnianego procentu 80 złp. Oprócz tego arcybractwo posiadało dochody z opłat wnoszonych przez osoby zapisujące się $\mathrm{w}$ jego poczet, ofiary $\mathrm{z}$ tacy zbieranej $\mathrm{w}$ czasie odpustów różańcowych trzy razy do roku, a także pieniądze z puszki różańcowej5 ${ }^{54}$. Wartość tych wpływów ilustruje tabela 2. Stałym źródłem dochodu był procent od kapitału w banku, zaś pozostałe zmieniały się corocznie i były uzależnione od liczby wpisujących się w poczet tej wspólnoty oraz od ofiarności wiernych w czasie nabożeństw arcybrackich.

Rozliczenia te zaczęto wpisywać do księgi arcybrackiej dopiero od 1875 r., kiedy wikariuszem kościoła św. Jakuba był ksiądz Ludwik Piotrowicz, wybrany również na promotora arcybractwa ${ }^{55}$. Przy wsparciu

52 ADS, Dominikanie Sandomierz 1845-1867, [brak sygn.], nlb., Pismo Wojciecha Gieleraka i Mateusza Józefowicza do konsystorza sandomierskiego z 30 IX 1865 r.; Pismo konsystorza sandomierskiego do Rządu Gubernialnego Radomskiego z 5 X 1865 r.

53 Ibidem, Pismo Rządu Gubernialnego Radomskiego do konsystorza sandomierskiego z 15/27 IX 1866 r.; Pismo konsystorza sandomierskiego do Tymoteusza Jaskulskiego rektora kościoła św. Jakuba z 8 X $1866 \mathrm{r}$. W pismach tych wymieniono również bractwo różańcowe w Obrazowie, które również miało odebrać 12 rb.

54 AKSJ, Książka, s. 234.

55 AKSJ, Książka, s. 240. Ksiądz Ludwik Roch Piotrowicz, profesor seminarium sandomierskiego, kanonik honorowy kapituły katedralnej sandomierskiej, wizytator klasztorów, od 1874 r. wikariusz podominikańskiego kościoła św. Jakuba, J. Wiśniewski, Katalog, s. 233-235. 
Tab. 2. Dochody arcybractwa w 1875 r.

\begin{tabular}{|l|c|}
\hline \multicolumn{1}{|c|}{ Źródło dochodów } & Wysokość dochodów \\
\hline Z procentu za rok 1875 w lipcu za kwitem magistratu & $80 \mathrm{złp}$ \\
\hline Z puszki kościelnej & $26 \mathrm{złp} 8$ gr \\
\hline Z opłat przy zapisywaniu się w arcybractwo & $60 \mathrm{złp} 10 \mathrm{gr}$ \\
\hline Z rocznych składek na światło & $90 \mathrm{złp} 28 \mathrm{gr}$ \\
\hline Łącznie & $257 \mathrm{złp} 16 \mathrm{gr}$ \\
\hline
\end{tabular}

Źródło: AKSJ, Książka, s. 234.

księdza Melchiora Bulińskiego ${ }^{56}$ przeniesiono obraz Matki Boskiej Różańcowej do kaplicy św. Walentego. Aby pomnożyć fundusz na tę kaplicę przemianowaną na różańcową, na zebraniu w $1875 \mathrm{r}$. ustalono wysokość stawek za msze św., uwzględniając należność dla celebrującego kapłana, organisty i arcybractwa. Przy zapisywaniu się w poczet tej konfraterni należało wpłacić 2 złp 10 gr na światło, natomiast członkowie corocznie powinni składać na ręce prokuratorów po 2 złp $^{57}$. Puszka arcybracka znajdowała się w zakrystii, tam też w szufladzie zamykano świece, których nie wolno było zabierać do innych kościołów, chyba że na wyraźną prośbę proboszcza innej świątyni. Świece pozostawały do wyłącznej dyspozycji konfratrów różańcowych. Dodatkowym źródłem dochodów były datki ofiarowane arcybractwu przez dobrodziejów, m.in. przez Pawła Wodza z Rzeczycy Suchej, który przekazał 300 złp na dywanik na stopnie do kaplicy oraz na sukienkę na obraz NMP Różańcowej, którą wykonały benedyktynki sandomierskie. W 1876 r. protektorka arcybractwa Brzesiańska ofiarowała $6 \mathrm{rb}$., które przekazano razem z dodatkową kwotą $(4,71 \mathrm{rb}$.) księdzu Bulińskiemu na renowację kościoła. Ponadto Julian Skorupski właściciel posiadłości sąsiadującej z kościołem św. Jakuba i były naczelnik

56 Melchior Buliński (1810-1877) - prałat kapituły katedralnej sandomierskiej, profesor Seminarium Duchownego w Sandomierzu, od 1851 r. profesor zwyczajny Historii Kościelnej w Akademii Duchownej Rzymsko-Katolickiej w Warszawie. Opracował dzieła: Historja Kościoła Powszechnego, t. 1-6 (Warszawa 1860-1866), Historja Kościoła Polskiego, t. 1-3 (Kraków 1873-1874) oraz Monografija miasta Sandomierza (Warszawa 1879), J. Wiśniewski, Katalog, s. 31-34; A. Wyrzykowski, Buliński Melchior, w: Polski Słownik Biograficzny, t. 3, Kraków 1937, s. 125.

57 AKSJ, Książka, s. 235. Za zamówioną mszę św. należało pobierać 6 złp 20 gr, a z tej kwoty 5 złp przekazać celebransowi, 1 złp do puszki arcybractwa, a 20 gr organiście. Za mszę różańcową przed obrazem NMP Różańcowej ustalono 5 złp (dla celebransa 3 złp 20 gr, do puszki 20 gr, kantorom po 20 gr), zaś za mszę czytaną 3 złp 10 gr (z tego 10 gr do puszki arcybrackiej). 
Komisji Rządowej Przychodów i Skarbu (KRPiS) w Warszawie dołożył się do wykonania żelaznej kraty w celu ogrodzenia cmentarza kościelnego ${ }^{58}$.

Wśród wydatków wymieniono także zakup świec (141 złp 8 gr), oprawę nabożeństw (15 złp 18 gr), inne potrzeby (19 złp 10 gr) oraz remont zalanego domku arcybrackiego (50 złp 28 gr). Mieszkali w nim kantorowie, czyli śpiewacy arcybractwa. Wydano łącznie 226 złp 4 gr, a pozostało $31 \mathrm{złp} 12$ gr. Aby wypełnić obowiązek wspierania potrzebujących, z pozostałej kwoty wydzielono jałmużnę (po 6 złp 20 gr) dla trzech osób, mianowicie dla starca Andrzeja Sobolewskiego i kantorek arcybractwa Marianny Komodzińskiej i Pauliny Bańkowskiej j9. Ksiądz Piotrowicz zasugerował, aby pozostałe pieniądze, a także te spodziewane $\mathrm{z}$ następnego roku zostały przeznaczone na zabezpieczenie od kurzu obrazu Matki Boskiej. Przy okazji należało wydostać spoza niego obraz św. Wincentego pozostawiony tam przez pośpiech, a także wyprostować ołtarz. Jeżeli by coś pozostało, to należało przeznaczyć na wykończenie drzwi kościelnych ${ }^{60}$. Informacje te świadczą że arcybractwo wspierało finansowo renowację całej świątyni, a także zapewniało należytą oprawę nabożeństwom różańcowym. Wymieniono wśród nich nabożeństwa z okazji odpustów w uroczystość NMP Różańcowej, Nowy Rok ku czci Imienia Jezus oraz na Emaus (wtorek po Wielkanocy), ponadto nieszpory we wszystkie święta maryjne i pierwszą niedzielę każdego miesiąca oraz msze różańcowe we wszystkie soboty w roku. Codziennie zaś kantorzy arcybractwa śpiewali cząstkę różańca ${ }^{61}$.

Na zebraniu w 1875 r. wybrano również zarząd arcybracki, złożony $z$ urzędów dla mężczyzn oraz kobiet ${ }^{62}$. Niestety nie sprecyzowano, jak

58 AKSJ, Książka, s. 235, 245. Na przełomie 1875 i 1876 r. łącznie przekazano Bulińskiemu na remont 31 złp 12 gr. Buliński w swojej pracy (Monografija miasta Sandomierza, s. 308) napisał, że odnowiono dach kościoła i kaplicę św. Jacka, na co rząd przeznaczył 6 tys. złp. Natomiast mieszczanin sandomierski Karol Staniszewski bezpłatnie wykonał wszystkie prace z tym związane, wykorzystał w tym celu anszlag (kosztorys) przygotowany przez budowniczego Jana Lasotę. O zaangażowaniu Bulińskiego w renowację kościoła św. Jakuba pisał J. Wiśniewski, Katalog, s. 31-35.

59 AKSJ, Książka, s. 240, 243.

60 AKSJ, Książka, s. 241.

61 AKSJ, Książka, s. 238.

62 AKSJ, Książka, s. 235. Promotorem tej wspólnoty został wybrany ksiądz Piotrowicz rektor kościoła św. Jakuba, a na promotorki: żony Szpota, Skorupskiego, Zalewskiego, Słomczyńskiego, Brzesiańskiego, Strużyńskiego i Domagalskiego. Przeorem arcybractwa został Dominik Brzozowski emerytowany mieszczanin, a subprzeorem Wojciech Gielerak z przedmieścia. Urząd przeoryszy pełnić miała Katarzyna Pogorzelska, zaś podprzeoryszy Wiktoria Kuraś. Funkcję skarbnika powierzono kupcowi sandomierskiemu Stanisławowi Pogorzelskiemu, podskarbiego - rzemieślnikowi Janowi Zdankowskiemu, podskarbiną 
długo miała trwać ich kadencja. Wśród protektorów arcybractwa znaleźli się biskup sandomierski J.M. Juszyński, prałat Melchior Buliński, Julian Skorupski, Teofil Szpot doktor medycyny, Cyprian Strużyński adiunkt w urzędzie powiatowym oraz dobrodziej arcybractwa Paweł Wódz ${ }^{63}$.

Kiedy przy kościele św. Jakuba przebywali dominikanie, corocznie wpisywało się do arcybractwa różańcowego po kilkadziesiąt osób, nawet w czasie trwania powstania styczniowego. W księdze arcybrackiej kilkakrotnie odnotowany został ojciec Jaskulski, jako podprzeor, a po kasacie klasztoru jako wikariusz wpisujący nazwiska nowych członków. Kiedy w 1870 r. opuścił klasztor, obowiązki te przejął rektor kościoła wyznaczany spośród duchowieństwa diecezjalnego.

\section{BIBLIOTEKA}

Księgozbiór klasztoru przy kościele św. Jakuba został przejęty na rzecz seminarium diecezjalnego w Sandomierzu 30 sierpnia 1866 r. Obecny przy tym był kanonik Józef Gacki wyznaczony przez biskupa sandomierskiego do przejęcia wszystkich bibliotek poklasztornych w diecezji sandomierskiej. Towarzyszyli mu prezydent Sandomierza Onufry Milczarski oraz sekretarz biura powiatu Cyprian Strużyński. Weszli do gmachu, gdzie znajdowała się biblioteka i stwierdzili, że drzwi do niej prowadzące posiadały nienaruszoną pieczęć. Otworzyli je i sprawdzili stan księgozbioru z otrzymanym katalogiem. Odnotowali, których książek brakowało na stanie i szukali przedmiotów, które mogłyby podlegać zajęciu na rzecz skarbu, jednak takowych nie znaleźli. Po zweryfikowaniu katalogu Milczarski i Strużyński zlecili jego przepisanie oraz zabranie książek do seminarium kanonikowi Gackiemu ${ }^{64}$. W oparciu o ten spis

została żona Pawła Wodza. Wybrano dwóch prokuratorów (mieszczanina Jana Wajruncha i organistę Władysława Skrzyńskiego) oraz sześć prokuratorek (Mariannę Pogorzelską, Cichocka, Mariannę Kobierska, Marię i Jadwigę Szpotową oraz Janinę Neskrowicz). Wśród servitores znaleźli się introligator Karczewski, Kazimierz Stec i Jan Kowalski, obaj z Kobiernik. Obowiązki prowizorek pełniły Marianna Gładysz, Marianna Ziembina i Marianna Sadkowska. Kantorzy i kantorki to: Tadeusz Calicki, Paulina Bańkowska, Franciszek Sobolewski, Marianna Karczewska, Mikołaj Łukawski i Marianna Komodzina. Do grona radnych wybrano właściciela apteki z Sandomierza Wilhelma Szymańskiego, rzemieślnika Piotra Dżbikowskiego, Kamila Staniszewskiego, Jana Misiórskiego z przedmieścia, profesora szkoły Józefa Wilkowskiego, cieślę Franciszka Sadkowskiego i Bartłomieja Statucha gospodarza z Milczan.

63 AKSJ, Książka, s. 235-237.

64 APR, RGR, sygn. 4265, s. 436. Zgodę na zabranie księgozbioru dominikańskiego (jak też innych zakonów) do seminarium diecezjalnego biskup J.M. Juszyński uzyskał od 
można stwierdzić, że z klasztoru dominikanów zabrano 836 książek. Natomiast $\mathrm{w}$ miejscu brakujących 47 pozycji zostawiano wolny wiersz, bez informacji o tytule lub autorze dzieła. Powody braków w księgozbiorze podał ojciec Jaskulski, kiedy w lipcu 1865 r. przesyłał katalog prezydentowi Sandomierza: „, Odsyłam katalog ksiąg z biblioteki podominikańskiej z Sandomierza lecz przez pożyczkę książek w różnych latach, a szczególniej przy kasacyji klasztoru toż zgromadzenie odjeżdżając pozabierało wiele dzieł, z tej więc przyczyny nie będę mógł się uiścić w oddaniu kompletnie książek według tegoż katalogu z tejże biblioteki”"65. O przekazanie katalogu, podobnie jak i list książek z innych klasztorów, poprosił biskup sandomierski J.M. Juszyński gubernatora cywilnego, celem oddania ich w ręce kanonika Gackiego. Miały one ułatwić mu sprawdzenie aktualnego stanu księgozbiorów, a także umożliwić zabranie i przewiezienie do seminarium, w razie gdyby ktoś chciał mu w tym przeszkodzić6 ${ }^{6}$.

W oparciu o ten katalog można stwierdzić, że księgozbiór podzielony był na dziewięć tematycznych działów i oznaczony literami od A do I. Pierwszy zawierał kilka wydań Biblii, konkordancje i komentarze biblijne, liczył 44 pozycje, spośród których brakowało 5. Kolejny dział oznaczony literą B zawierał 57 dzieł Ojców Kościoła, ale 3 nie znaleziono. Najobszerniejszy w całym księgozbiorze był trzeci, poświęcony teologii scholastycznej i ascetycznej, liczył 202 pozycje z 13 brakującymi. Pod literą D wynotowano 81 (10 brakowało) opracowań poświęconych historii kościelnej i świeckiej. Następna część biblioteki powinna zawierać 78 dzieł, ale nie odnaleziono $9 \mathrm{z}$ nich, gromadziła książki o tematyce filozoficznej. Z kolei prawo kanoniczne i świeckie wynotowano w dziale pod literą F, powinien on liczyć 34 woluminy, w rzeczywistości było o 3 mniej. Dwa następne działy obejmowały dzieła poświęcone kaznodziejstwu, a zostały one rozdzielone ze względu na język, w jakim zostały opublikowane, mianowicie pod Literą $G$ wpisano opracowania w języku łacińskim (165 pozycji, brakowało 4), zaś pod literą $\mathrm{H}-\mathrm{w}$ języku polskim (67). Ostatnia część księgozbioru zawierała 155 pozycji medytacji, ćwiczeń duchownych, rozważań o tajemnicach różańcowych i rekolekcji. Na końcu wynotowano mszały dominikańskie, brewiarz, agendkę i psałterz ${ }^{67}$.

namiestnika Królestwa Polskiego jeszcze w marcu 1865 r., APR, RGR, sygn. 4264, s. 392393.

APR, RGR, sygn. 4264, s. 773.

Ibidem, s. 774-775.

67 APR, RGR, sygn. 4265, s. 437-495. Katalog ten zamieszczono w dwóch egzemplarzach jako: Konsygnacya ksiażek w bibliotece po księżach dominikanach w Sandomierzu znajdujacych się $i$ sprawdzonych $w$ dniu 18/30 sierpnia 1866 r. z egzemplarzem na gruncie przez delegowanych do tej czynności reskryptem W[ielmożneg]o Naczelnika Powiatu Sandomierskiego z dnia 28 czerwca/10 lipca 1865 r. 
Przy weryfikacji księgozbioru posłużono się wspomnianym wyżej katalogiem sporządzonym w 1860 r., o czym świadczy adnotacja w piśmie skierowanym do gubernatora cywilnego z 1865 r. Relacjonowano w nim, które biblioteki posiadały katalogi, a w których ich brakowało: „Katalog książek biblioteki XX Dominikanów w Sandomierzu znaleziony został przy zamknięciu klasztoru, lecz do operatu zajęcia nie został załączony". Mimo to uznano księgozbiór za nieuporządkowany i wymagający dokładnego opisu, do którego potrzeba było czasu i znajomości języków ${ }^{68}$.

4 października 1866 r. biskup sandomierski J.M. Juszyński odpowiadając na pismo gubernatora cywilnego guberni radomskiej, relacjonował, że dotychczas przewieziono do seminarium diecezjalnego księgozbiory dziewięciu bibliotek poklasztornych, w tym również tej należącej do dominikanów sandomierskich ${ }^{69} .17$ listopada 1866 r. naczelnik powiatu sandomierskiego złożył raport do Rządu Gubernialnego Radomskiego o przygotowaniu w dwóch egzemplarzach katalogów zabranych bibliotek z klasztoru dominikanów sandomierskich, a także franciszkanów z Zawichostu i reformatów z Rytwian ${ }^{70}$. Tym samym zakończono akcję przewożenia księgozbioru dominikańskiego z klasztoru przy kościele św. Jakuba do seminarium diecezjalnego.

\section{BUDYNEK KLASZTORNY}

Budynki poklasztorne przejęte przez rząd rosyjski wkrótce zostały spożytkowane przez lokalne władze administracyjno-wojskowe. Otóż już w 1865 r. w zabudowaniach klasztornych urządzono koszary dla wojska i stajnie dla koni oddziału kozackiego. Polecenie takiej treści wydał naczelnik wojenny powiatu sandomierskiego, uzasadniając to brakiem pomieszczeń dla żołnierzy ${ }^{71}$.

68 APR, RGR, sygn. 4264, s. 436, 439; D. Burdzy, Biblioteka dominikańskiego klasztoru św. Jakuba Apostoła w Sandomierzu w świetle katalogu z 1860 r., w: Arma nostrae militiae. Kultura książki i pisma Zakonu Kaznodziejskiego na ziemiach polskich, red. I. Pietrzkiewicz, M. Miławicki, Poznań 2019, s. 115-127.

69 APR, RGR, sygn. 4265, s. 364-365. Oprócz bibliotek dominikanów sandomierskich w seminarium diecezjalnym znajdowały się już te należące do bernardynów z Radomia i Opatowa, pijarów z Radomia, reformatów z Solca, Rytwian i Sandomierza, franciszkanów z Zawichostu oraz z Instytutu Księży Demerytów na Łysej Górze. Opóźnienie w sprowadzeniu do Sandomierza zasobu trzech innych bibliotek (z Kazanowa, Smardzewic i Studzianny) tłumaczył nieobecnością delegata rządowego powiatu opatowskiego, dlatego prosił o przedłużenie terminu na przewiezienie tych księgozbiorów.

70 Ibidem, s. 393.

71 Ibidem, s. 320-321, 325-327; E. Orzechowska, Własność, s. 204-205. 
W lutym 1865 r. sporządzono opis zabudowań klasztornych przy kościele św. Jakuba, aby sprawdzić, czy będzie je można przekazać w użytkowanie jakiemuś urzędowi. Klasztor był kryty gontem, składał się z jednego, jak to określono, piętrowego pawilonu i korytarzy zbudowanych w okólnik, do których przylegały składy drzewa i chlewy. Wszystko było w stanie podupadłym i opuszczonym. Gmach klasztorny mieścił na dole zakrystię, spiżarnię, refektarz, małe mieszkanie dawnego przeora i kuchnię. Na parterze zaś znajdowało się kilka cel ogrzewanych i biblioteka bez pieca. Pomieszczenia te usytuowane były po dwóch stronach szerokiego korytarza. Stwierdzono, że gmach ten trudno byłoby dostosować do potrzeb jakiejkolwiek dykasterii przede wszystkim z powodu złego stanu i szczupłości miejsca, ale także z braku dostępu do dobrej drogi. Klasztor bowiem był usytuowany za głębokim parowem, poza miastem, w nieuczęszczanej okolicy. Prowadziła do niego stroma ścieżka, trzeba było także przejść przez most, który był własnością prywatną. Część dolna gmachu, a nawet kilka cel na piętrze powinna być oddana na użytek administratora kościoła, organisty i posługacza. Natomiast resztę pomieszczeń najlepiej byłoby oddać władzy diecezjalnej do rozporządzenia, ponieważ nie miała miejsca na ulokowania księży demerytów ( tzw. księży zdrożnych). Pierwsze piętro klasztoru byłoby więc odpowiednie na ten cel.

Stodoła drewniana kryta słomą po wydzierżawieniu gruntów miała być sprzedana na licytacji albo również oddana w dzierżawę. Drewniany domek stojący za ogrodem był w złym stanie, dlatego najwłaściwszym byłoby go sprzedać. Przy klasztorze znajdował się niewielki ogród, który należało oddać w posiadanie wikariusza kościoła św. Jakuba ${ }^{72}$.

Przygotowano kosztorys remontu, który należało przeprowadzić w podominikańskim klasztorze. Budowniczy powiatu sandomierskiego wezwał dwóch znawców, z którymi oszacował koszt materiałów budowlanych oraz transportu i robocizny. Zanotowano, że potrzebna była cegła, kamień, wapno, krokwie, łaty, tarcice, różnej wielkości gwoździe, które trzeba było sprowadzić (lądem lub spławić Wisłą) z różnych miejscowości (z Kamienia Mściowskiego, Dwikóz, Łagowa, Ożarowa). Całość planowanego przedsięwzięcia oszacowano na ponad $150 \mathrm{rb} .^{73}$ Klasztor został dokładnie wymierzony przez budowniczego Jana Lassotę, który w maju $1865 \mathrm{r}$. przygotował trzy plany gmachu oraz kościoła i przylegającego do nich terenu ${ }^{74}$. Jednak planowany remont nie został wówczas przeprowadzony,

72 APR, RGR, sygn. 4265, s. 343-344.

73 Ibidem, s. 341-342.

74 Ibidem, s. 328-340. Plany klasztoru nakazano sporządzić jeszcze na początku $1865 \mathrm{r}$. APR, RGR, sygn. 4264, s. 132-135, 305-307, 324, 325, 327-328, 402. Dokładne pomiary 
w grudniu 1867 r. biskup J.M. Juszyński prosił o środki na remont zabudowań klasztornych, ponieważ chciał w nim ulokować księży demerytów z diecezji sandomierskiej. Pomimo iż władze wyznaczyły na ten cel klasztor etatowy w Wysokim Kole, to jednak biskup tłumaczył, że będzie mógł sprawować pełniejszą kontrolę nad kapłanami demerytami, jeżeli będą przebywać w stolicy diecezji. Prosił więc o wyasygnowanie funduszy na przeprowadzenie koniecznej renowacji podominikańskiego gmachu ${ }^{75}$. Z informacji przekazanych przez księdza Melchiora Bulińskiego wynika, że rząd przeznaczył sześć tys. złp na naprawę dachu na kościele oraz na przebudowanie mieszkania dla rektora tej świątyni ${ }^{76}$.

9 sierpnia 1866 r. Komitet Urządzający w Królestwie Polskim w odpowiedzi na propozycje naczelnika wojennego oddziału radomskiego generała lejtnanta Walerego Bellegarde'a przedstawił rozwiązania ustalone na posiedzeniu osobnej komisji o klasztorach (z 20 marca 1866 r.) dotyczące pomieszczeń po skasowanych klasztorach. Bellegarde chciał, aby przeznaczyć pomieszczenia niektórych skasowanych klasztorów na koszary dla wojska. Jednak KRSWiD zdecydowała się oddać cztery gmachy klasztorne, mianowicie podominikański w Sandomierzu, pobernardyński w Kazanowie pod Końskimi, pofranciszkański w Nowym Mieście Korczynie oraz poaugustiański w Książu Wielkim w zarząd magistratów miast, w których się znajdowały. Wcześniej należało wydzielić pomieszczenia dla duchowieństwa i służby pozostającej do obsługi kościołów. Istotną kwestią było także oddanie na użytek tych duchownych ogrodów warzywnych i owocowych, ze względu na ich trudną sytuację materialną. Nakazano ponadto ,,[...] natychmiastowe sporządzenie planu tegoż klasztoru i miejscowości do niego należącej, wykazującego szczegółowo obszerność tej miejscowości i to wszystko, co się w niej znajduje, podział jej pomiędzy różne władze, a następnie plan takowej z protokołem dokładnie położenie całej miejscowości opisującym i swemi wnioskami projektującemi oddzielnie części do kościoła należeć mających i rozdzielenie całej miejscowości, w czasie jak można najprędszem, a najpóźniej w ciągu jednego miesiąca do dalszego rozporządzenia i wyjednania stanowczej decyzji Rządowi Cywilnemu przedstawić" ${ }^{77}$.

klasztoru z zabudowaniami oraz gruntami usytuowanymi w jego sąsiedztwie, a także zlokalizowanymi w różnych częściach Sandomierza sporządził w postaci tabeli geometra rządowy Krupiński w 1866 r., APR, ZDP, Sukcesje, sygn. 9602, nlb.

75 ADS, Dominikanie Sandomierz 1845-1867, [brak sygn.], nlb., Pismo biskupa sandomierskiego J.M. Juszyńskiego do Gubernatora Cywilnego Guberni Radomskiej z 18/30 XII $1867 \mathrm{r}$.

76 M. Buliński, op. cit., s. 308.

77 APR, RGR, sygn. 4265, s. 194-198, 201, 204-205. Szczegółowe rozporządzenia odnośnie do ogrodów przy klasztorach etatowych i zniesionych wydane zostały we wrześniu 
Magistrat Sandomierza przejął gmach klasztoru w marcu $1867 \mathrm{r}$. W protokole były asesor ekonomiczny okręgu sandomierskiego sprecyzował, że oprócz samego budynku klasztornego w zarząd miasta oddane zostały także zabudowania gospodarcze otoczone wspólnym murem, mianowicie obora na krowy z chlewem, stajnia na konie i wozownia. Natomiast pozostałe, czyli stodoła i dom z chlewem położone poza murem klasztornym, zostały zajęte na Skarb Państwa i zakwalifikowane do sprzedaży na licytacji. Przy tej okazji sporządzono opis, który wykazywał, że budynek poklasztorny był zaniedbany, wiele pomieszczeń było zrujnowanych i nienadających się do mieszkania. Tylko kilka spośród jedenastu cel na piętrze mogło być użytkowanych. Protokół odebrał prezydent miasta Onufry Milczarski ${ }^{78}$.

\section{ZAJĘCIE MAJĄTKU DOMINIKANÓW SANDOMIERSKICH}

24 grudnia 1864 r. radomski gubernator cywilny zawiadomił dyrektora głównego, że wypełnił ukaz z dnia 7 grudnia, wydany przez naczelnika wojennego powiatu sandomierskiego dotyczący zamknięcia klasztoru księży dominikanów w Sandomierzu ${ }^{79}$. Kolejnym krokiem było przystąpienie do spisania majątku należącego do klasztoru w celu jego wyprzedaży lub wydzierżawienia. 10 stycznia $1865 \mathrm{r}$. asesor ekonomiczny Antoni Jurkowski, wydelegowany do zajęcia majątku w posiadanie skarbu, donosił gubernatorowi generałowi Henrykowi Konstantemu Fanshawe'owi o ogłoszeniu licytacji na trzodę chlewną i sprzęty klasztorne oraz prosił o pozwolenie na sprzedaż zboża. Relacjonował, że po przybyciu do klasztoru (w oparciu o reskrypt z 16 grudnia 1864 r.) przejrzał spis majątku i zdecydował, że niektóre sprzęty znajdujące się w klasztorze i w folwarkach oraz 10 sztuk trzody chlewnej nadają się na sprzedaż. Pieniądze, jakie spodziewał się uzyskać z licytacji, miały być wniesione (według reskryptu z 19 grudnia 1864 r.) do depozytu kasowego. Jednak zaznaczył, że część tych pieniędzy musi być przeznaczona na wypłatę dla służby klasztornej i folwarcznej oraz najemnych pracowników tych

1866 r. Ibidem, s. 310-315.

78 APR, ZDP, ISR, sygn. 281, k. 1-3v, 6-7v. W tym czasie władze wydały dwa sprzeczne polecenia, mianowicie jedno w sprawie oddania w zarząd miasta Sandomierza klasztoru i budynków gospodarczych, a drugie dotyczące wydzierżawienia niektórych budynków na rzecz skarbu. Zwrócił na to uwagę asesor ekonomiczny, informując o tym gubernatora i namiestnika. Skoro nie otrzymał odpowiedzi, zrealizował polecenie przekazania klasztoru podominikańskiego magistratowi Sandomierza. Ibidem, k. 4-4v.

79 APR, ZDP, Sukcesje, sygn. 9601, k. 2. 
gospodarstw. Podał ich listę razem z wysokością zaległego wynagrodzenia, które łącznie opiewało na sumę 300,87 rb. Do tego doliczył jeszcze resztę zapłaty dla Tekli Piskorowej z Jugoszowa za woła przekazanego na ten folwark (9 rb.), co w sumie dawało 309,87 rb.

Tab. 3. Wydatki na wynagrodzenie dla służby w klasztorze oraz w folwarkach w Jugoszowie i Gołębicach (1865 r.)

\begin{tabular}{|l|c|l|c|l|c|}
\hline $\begin{array}{c}\text { Służba } \\
\text { w klasztorze }\end{array}$ & $\begin{array}{c}\text { Zapłata } \\
\text { w rublach }\end{array}$ & $\begin{array}{c}\text { Służba na fol- } \\
\text { warku Jugoszów }\end{array}$ & $\begin{array}{c}\text { Zapłata } \\
\text { w rublach }\end{array}$ & $\begin{array}{c}\text { Służba na fol- } \\
\text { warku Gołębice }\end{array}$ & $\begin{array}{c}\text { Zapłata } \\
\text { w rublach }\end{array}$ \\
\hline Gospodyni & 30,00 & Ekonom & 22,50 & Pisarz & 8,00 \\
\hline Dozorca & 4,50 & & - & Dozorca & 8,00 \\
\hline Służący & 5,00 & Służba & 43,00 & Służba & 56,00 \\
\hline Wyrobnica & 3,00 & Najemnicy & 104,60 & Najemnicy & 16,27 \\
\hline Razem & 42,50 & Razem & 170,10 & Razem & 88,27 \\
\hline Łącznie & \multicolumn{5}{|l}{} \\
\hline
\end{tabular}

Źródło: APR, ZDP, Sukcesje, sygn. 9601.

Konieczność uregulowania należności asesor argumentował potrzebą utrzymania w dobrym stanie gospodarstwa na przyszłość oraz zapobieżenia ciągłym naleganiom ze strony służby i robotników. Przewidywał, że z licytacji otrzyma 100 rb., więc brakującą część chciał uzyskać ze sprzedaży zboża, które zbywało w gospodarstwie. Dlatego skierował prośbę do gubernatora o pozwolenie na tego typu transakcję $e^{80} .24$ stycznia $1865 \mathrm{r}$. otrzymał zgodę, jednak powinien najpierw wydzielić zboże niezbędne do wyżywienia czeladzi dworskiej w folwarkach oraz zwierząt, a także pod zasiew. Dopiero wówczas, jeśli byłyby nadwyżki, asesor mógł je sprzedać na publicznej licytacji ${ }^{81}$. Zanim otrzymał odpowiedź, 19 stycznia 1865 r. wysłał kolejne pismo do gubernatora, ponieważ pojawiły się dodatkowe komplikacje. Otóż naczelnik wojenny wystosował do asesora pismo dotyczące dwóch sandomierskich Żydów: Icka Rużanego i Borucha Cukerbluma, którzy kupili zboże u księdza Machnickiego, byłego już przeora dominikanów sandomierskich. Ickowi należało wydać 61 korcy pszenicy i 10 korcy prosa ${ }^{82}$. Natomiast Boruch domagał się wydania 9 korcy pszenicy i 14 korcy żyta. Asesor Jurkowski prosząc gubernatora o decyzję w tej sprawie, zwrócił uwagę, że „[...] zboże sprzedane uważając

\footnotetext{
80 Ibidem, k. 5-6.

81 Ibidem, k. 7-7v.

82 Ibidem, k. 8-8v. Pomimo iż Icek otrzymał jeszcze przed kasatą 29 korcy pszenicy (z folwarku w Jugoszowie 23 korce, a z folwarku w Gołębicach - 6 korcy), to jednak okazało się, że dokupił jeszcze wymienione $\mathrm{w}$ reskrypcie ilości zboża.
} 
nie jako dług klasztoru, ale jako depozyt własność prywatną stanowiący i z tego powodu zajęciu pod zawiadywanie skarbu nie podlegający [...]", powinno być niezwłocznie wydane obu Żydom. Ponadto dominikanie nie oddali dziesięciny za 1864 r. (z gruntów przy klasztorze i z folwarków w Jugoszowie i Gołębicach) dla kapituły katedralnej sandomierskiej, dla kościoła św. Pawła w Sandomierzu oraz dla kościoła w Goźlicach, co łącznie dawało 33 korcy i 1/2 garnca żyta. Istniała możliwość uregulowania tych zobowiązań, ponieważ w małym spichlerzu w Jugoszowie nie można było zmagazynować już wiele zboża, a w stodołach było bardzo dużo niewymłóconego. Trzeba było je niezwłocznie wymłócić, aby wykorzystać o tej porze tańszą siłę najemna, a ponadto uchronić zboże w snopie przed niszczeniem przez szczury. Nie było ono ubezpieczone w Dyrekcji Ubezpieczeń, dlatego w razie pożaru mogłyby powstać ogromne straty ${ }^{83}$. Wkrótce asesor otrzymał zgodę na wydanie zboża Żydom i wspomnianym instytucjom kościelnym, natomiast powinien czekać na decyzję odnośnie do ubezpieczenia zapasów w Dyrekcji Ubezpieczeń ${ }^{84}$.

4 marca 1865 r. asesor Jurkowski donosił generałowi gubernatorowi Fanshawe'owi, że przeprowadził zlecone mu przejęcie majątku po zniesionym klasztorze, jednak nie udało mu się zaprowadzić formalnej administracji na obu folwarkach, „,...] bo żaden z ościennych obywateli takowej przyjąć nie chciał [...]", więc był zmuszony pozostawić zarząd folwarku w gestii miejscowego ekonoma, a w Gołębicach - dozorcy i pisarza z dzienną płacą odpowiednio 30 kop. i 20 kop. Wykaz potrzeb związanych $\mathrm{z}$ administracją miał przesłać w późniejszym czasie, jednak zapewnił, że są wystarczające fundusze na prowadzenie gospodarstw do 1 czerwca 1865 r. Za sprzedane ruchomości, trzodę chlewną i zboże uzyskał 724,40 rb. ${ }^{85} \mathrm{Z}$ tej sumy wydał 558,60 rb., zaś resztę (165,80 rb.) złożył do depozytu $\mathrm{w}$ kasie powiatowej sandomierskiej. Sugerował jednak w piśmie, że zdeponowane pieniądze należałoby przeznaczyć na wypłatę zaległych wynagrodzeń włościanom (140,85 rb.), a resztę sumy $(24,95 \mathrm{rb}$.) przekazać ekonomowi folwarku w Jugoszowie na przynajmniej częściowe

\footnotetext{
83 Ibidem, k. 8-9v.

84 Ibidem, k. 10-11v.

85 Nie sprzedał bydła, któremu na przełomie października i listopada 1865 r. zaczęła grozić epidemiczna choroba zwana karbunkułem. Wówczas asesor ekonomiczny Jurkowski zwrócił się do rządu gubernialnego z wnioskiem sprzedaży inwentarza żywego na folwarkach skasowanych klasztorów, w tym Jugoszowa i Gołębic. Ponadto zwrócił uwagę na powszechny brak paszy $\mathrm{w}$ tych folwarkach, jako że gospodarstwa były niedbale prowadzone. Zwierzęta były stare, dlatego aby ustrzec się przed stratami spowodowanymi dodatkowo choroba, prosił o decyzję w sprawie spieniężenia poprzez licytację inwentarza żywego. Wkrótce też uzyskał zgodę na sprzedaż, ale tylko z Gołębic i Kichar, należących do benedyktynek sandomierskich. APR, RGR, sygn. 5040, k. 201-202v.
} 
uregulowanie należności za najem i inne wydatki związane z prowadzeniem gospodarstwa $(120,655 \mathrm{rb}$.). Prosił także o upoważnienie na wypłacenie z kasy powiatowej odpowiednich funduszy, które pozwoliłyby na uregulowanie wszystkich zobowiązań. Wezwał naczelnika powiatu sandomierskiego majora Sergiusza Gołubowa, by uprzedził wszystkich zobowiązanych do płacenia czynszów klasztorowi, aby przekazywali je do kasy powiatowej. Na koniec prosił gubernatora o zwrot kosztów podróży i diet w wysokości 28,60 rb., a także o wypłatę zaliczki $50 \mathrm{rb}$. z kasy powiatowej, ponieważ wyjeżdżając do Klimontowa, nie miałby się z czego tam utrzymać.

Z 6 maja 1865 r. pochodzi obszerny raport przesłany do KRPiS, w którym zrelacjonowano pobieżnie okoliczności zniesienia klasztoru oraz przedstawiono bardzo szczegółowy spis majątku. Dołączono do tego protokół naczelnika wojennego dotyczący zniesienia klasztoru razem $\mathrm{z}$ jego opisem, protokół zajęcia $\mathrm{w}$ zarząd skarbu majątku dominikanów (15 foliałów i 2 zeszyty dowodów razem z lustracją folwarków), protokół ustanowienia dozoru i zarządu gospodarstwa na folwarkach Gołębice i Jugoszów, a także spis tabelaryczny majątku z 1859 r. z dołączonymi dokumentami. Szczegółowy opis uposażenia został wykonany 24 listopada 1864 r., porównano go ze spisem wykonanym dla Komisji Rządowej Spraw Wewnętrznych, Duchownych i Oświecenia Publicznego z 17 grudnia 1853 r. Według niego w skład majątku wchodził: klasztor z przyległymi do niego budynkami, ogród i grunty przyklasztorne oraz plac po spichlerzu. W dalszej kolejności zostały wymienione czynsze z placów i budynków, czynsz z czwartej części rybołówstwa na Wiśle i Wisełce oraz kapitały. W skład uposażenia wchodziły także wspomniane dwa folwarki w Gołębicach i Jugoszowie oraz lasy.

Piętrowy klasztor był połączony z kościołem, cały kompleks wykonany był z cegły i kryty gontem. Zabudowania gospodarcze tworzyły: drewniana obora (w źródle: stajnia) na krowy z chlewami na trzodę, przylegająca do spichlerza, murowana stajnia dla koni oraz sąsiadująca z klasztorem murowana wozownia i trzy inne budynki. Wszystkie były kryte gontem. Przeor wydzierżawił wozownię na skład drzewa za opłatą 15 rb., których za 1864 r. dzierżawca nie uiścił. Dochody te przeznaczono na zapłacenie długów klasztornych. Stodoła była drewniana i pokryta słomą. Dwadzieścia dziewięć prętów od klasztoru stał drewniany dom mieszkalny, kryty gontem, do którego przylegał chlewik również z drzewa. Te dwa budynki razem z częścią ogrodu zostały wydzierżawione przez przeora Machnickiego 15 kwietnia 1863 r. na okres trzech lat niejakiemu Mirosławskiemu za 30 rb. czynszu. Postanowiono skrócić czas dzierżawy o rok i sprzedać dom na publicznej licytacji, a plac z kawałkiem ogrodu wydzierżawić nabywcy domu. Ogrody, w których uprawiano 
warzywa (3/4 powierzchni) i owoce (1/4 powierzchni), usytuowane były za kościołem św. Pawła oraz na Zawisełczu. KRSWiD zdecydowała, że pozostanie on do użytku duchownego przebywającego przy kościele św. Jakuba. Część ogrodów przeznaczona była na grunty orne, w całości zlokalizowane za wspomnianym kościołem św. Pawła. Nie były one obsiane, więc zdecydowano, że zostaną wydzierżawione na okres jednego roku. Do tej kategorii zaliczono jeszcze plac po spichlerzu, który również powinien być wydzierżawiony, tym bardziej że do tej pory nie przynosił żadnego dochodu. Na trzech innych placach znajdujących się na terenie miasta Sandomierza postawione były budynki i wynajęte mieszczanom za czynsz roczny płacony w czerwcu (Mariannie Domańskiej, Ludwikowi Mazurkowi i Mariannie Rozłowskiej).

Dominikanie mieli prawo do $1 / 4$ części dochodów pobieranego przez kasę miejską z dzierżawy rybołówstwa na Wiśle i jej odnodze - Wisełce. Uzyskali je w oparciu o decyzję rządu gubernialnego sandomierskiego 30 marca 1838 r. Za rok 1864 został wypłacony czynsz w wysokości 25,025 rb. Dzierżawa zawarta była do 1866 r., więc zdecydowano, że przyszłe dochody powinny być odebrane z kasy miejskiej.

Przy opisie obu folwarków wyszczególniono inwentarz żywy oraz różne sprzęty i narzędzia rolnicze, które pozostawiono do dalszego użytku. Natomiast trzoda i drób zostały sprzedane za 89,58 rb., podobnie jak część sprzętów z klasztoru za 106,73 rb., reszta pozostała do bieżącego użytku dla ojca Tymoteusza Jaskulskiego. Sprzedane zostały także dwa wieprze, hodowane przy klasztorze za $90 \mathrm{rb}$. Na folwarku w Jugoszowie znaleziono dwie jałówki, które według zeznań miejscowych ludzi były osobistą własnością byłego przeora Machnickiego, po które zgłosił się on ze stosownym podaniem. Opierając się na $\S 42$ przepisów dodatkowych do najwyższego ukazu z 8 listopada 1864 r., który wyłączył z zajęcia na rzecz skarbu osobisty majątek zakonników, wydano przeorowi wspomniane zwierzęta i postanowiono zawiadomić o tym także magistrat Sandomierza. Przeor wystawił pokwitowanie za odebranie jałówek 4 czerwca 1865 r. w Klimontowie, przy okazji zaznaczył, że były one własnością jego ojca i trzymane na folwarku w Jugoszowie czasowo na zimowisku ${ }^{86}$.

Na Skarb Państwa zostały przejęte także oszczędności klasztoru w wysokości 6985,40 rb., przechowywane częściowo w banku (6323,40 rb.), a częściowo zabezpieczone na hipotekach (660 rb.), m.in. na dobrach wsi Strzyżowice, Przyborowice, na dwóch folwarkach Kobierniki, na folwarku Chwałki, na gruntach Branickich oraz na sześciu domach w Sandomierzu (należących do Stanisławskich, Dutreppiego, Jordana, Dziarskiego, Rogowskiego, Szefera vel Szlamy Kandel).

\footnotetext{
86 APR, ZDP, Sukcesje, sygn. 9601, k. 62.
} 
Oba folwarki w Gołębicach i Jugoszowie zostały szczegółowo opisane $\mathrm{w}$ osobnej lustracji. Włościanie na mocy najwyższego ukazu z dnia 2 marca 1864 r. zostali uwłaszczeni i zwolnieni od wszelkich powinności pańszczyźnianych. Dlatego zdecydowano, że oba folwarki odległe od siebie o dwie mile powinny być osobno wydzierżawione. Do pierwszego folwarku należały wsie Gołębice i Sucharzów, w ich sąsiedztwie znajdowały się lasy dębowy i sosnowy, natomiast przy folwarku Jugoszów był las grabowy. Wszystkie te lasy już od dawna pozostawały $w$ administracji rządu pod nadzorem Urzędu Leśnego Łagów ${ }^{87}$.

Wśród wydatków i zobowiązań wymieniono także długi prywatne, obciążające majątek klasztoru. W pierwszej kolejności podano kwotę należną dwóm klerykom dominikańskim: Ewarystowi Rutkowskiemu i Kajetanowi Kwitkowi za 1864 r. (w wysokości po 15 rb. każdy), następnie ojcu Tymoteuszowi Jaskulskiemu (wg podania z 15 lutego 1865 r. 35,40 rb.) i ojcu Ildefonsowi Kolińskiemu (wg rewersu z 2 stycznia 1865 r. 17,25 rb.). Wśród wierzycieli byli ponadto kupcy sandomierscy i warszawscy (w tym żydowskiego pochodzenia), miejscowy rzeźnik i szklarz, co w sumie dawało 917,02 rb. Doliczając do tego zaległości z podatków gruntowych, kwoty na zapłatę dla służby w gospodarstwach i dla robotników najemnych oraz różne potrzeby gospodarskie i wspomniane długi prywatne, całość zobowiązań klasztoru opiewała na sumę 1621,90 rb. Wspomniano także o sumie 182,38 rb. należnej klasztorowi św. Jakuba za utrzymywanie dwóch księży demerytów z klasztoru na Łysej Górze (211 dni, od 1 maja do 27 listopada 1864 r.). Protokół podpisali obecni przy zamknięciu klasztoru były przeor dominikanów, dziekan Saturnin Goltz, prezydent miasta Sandomierza Onufry Milczarski i asesor ekonomiczny Jurkowski.

29 marca 1865 r. do naczelnika powiatu sandomierskiego trafił raport (z 16 grudnia 1864 r.), w którym prezydent Sandomierza prosił o wypłatę diet i zwrot kosztów podróży poniesionych z racji asystowania przy kasacie klasztoru dominikańskiego i lustracji folwarków (47,88 rb.), a także zapłaty dla dozorcy Antoniego Dobrowolskiego, który pilnował ruchomości w klasztorze przez 15 dni (4,50 rb.). Odpowiedź z Rządu Gubernialnego Radomskiego nadeszła dopiero 31 sierpnia 1865 r., na mocy której pozwolono, aby kasa powiatu sandomierskiego wypłaciła żądane sumy dla prezydenta Milczarskiego oraz dozorcy Dobrowolskiego ${ }^{88}$. Asesor ekonomiczny Antoni Jurkowski otrzymał 22 rb. 12 i pół kopiejki jako rekompensatę za koszty podróży oraz diety poniesione $\mathrm{w}$ czasie przejmowania majątku podominikańskiego ${ }^{89}$.

\footnotetext{
87 Ibidem, k. 34v.

88 Ibidem, k. 48-49v.

89 Ibidem, k. 54v-55.
} 
Klasztor dominikanów sandomierskich przy kościele św. Jakuba podzielił los innych klasztorów w Królestwie Polskim objętych ukazem kasacyjnym 8 listopada 1864 r. Majątek został przejęty na Skarb Państwa, po zlicytowaniu zboża, inwentarza żywego i martwego oraz po wydzierżawieniu gruntów przyniósł wymierny zysk władzom zaborczym. Gmach klasztorny został zajęty przez wojsko na koszary, a część budynków gospodarczych na stajnie dla koni oddziału kozackiego. W 1867 r. klasztor został oddany w zarząd magistratu Sandomierza. Księgozbiór dominikanów sandomierskich, tak jak większości skasowanych klasztorów diecezji sandomierskiej, trafił do seminarium diecezjalnego, a wszystkie procedury z tym związane wykonał kanonik Gacki.

Kościół św. Jakuba jako filialny został oddany pod zarząd biskupa sandomierskiego. Obowiązki wikariusza do 1870 r. pełnił w nim dominikanin Tymoteusz Jaskulski, następnie zastąpił go ksiądz diecezjalny. Władze pozwoliły na dalszą działalność arcybractwa różańcowego, które dbało o rozwój kultu maryjnego, partycypowało w kosztach remontu świątyni i oświetlenia kaplicy różańcowej. Wspierało także finansowo ubogich.Kasata klasztoru zakończyła ponad 600-letni okres działalności dominikanów w Sandomierzu, zakonnicy zostali przeniesieni do klasztoru etatowego $\mathrm{w}$ Klimontowie, który $\mathrm{w}$ ciągu kilku lat wielu $\mathrm{z}$ nich opuściło na stałe, otrzymując sekularyzację (przeniesienie w szeregi duchowieństwa diecezjalnego).

\section{ANEKS}

W aneksie został zamieszczony szczegółowy protokół z przejęcia majątku klasztoru dominikanów sandomierskich przy kościele św. Jakuba ${ }^{90}$. Sporządzony został w $1865 \mathrm{r}$. przez asesora ekonomicznego powiatu sandomierskiego Antoniego Jurkowskiego, a podpisany przez prezydenta miasta Sandomierza Onufrego Milczarskiego oraz dziekana sandomierskiego Saturnina Goltza. W czynnościach tych uczestniczył także były przeor dominikanów Paulin Machnicki.

Działo się w mieście Sandomierzu dnia 9/21 lutego 1865 r.

Protokół przyjęcia pod zarząd Skarbu majątku po zniesionym klasztorze XX. Dominikanów w Sandomierzu

Podług Najwyższego Ukazu z dnia 27 października/8 listopada 1864 r. Najwyższej zatwierdzonych dodatkowych przepisów o klasztorach rzymsko-katolickich w Królestwie Polskim, wszystkie majątki składające się z dóbr, domów i kapitałów należących do klasztorów odebrane być mają w zawiadywanie Skarbu Królestwa,- wykonaniu więc tej

90 Ibidem, k. 25-40. 
Najwyższej Woli i w zastosowaniu się do Reskryptu JW. Gubernatora Cywilnego Guberni Radomskiej z dnia 5/17 grudnia 1864 r. n[umer] 75723 na Reskrypcie Komissyi Rządowej Przychodów i Skarbu z dnia 21 listopad/3 grudnia 1864 r. n[umer] 57152 opartego, delegowani, a mianowicie:

Ze strony Skarbu Assesor Ekonomiczny biurowy przy Rządzie Gubernialnym Radomskim, Antoni Jurkowski;

Ze strony administracyjnej Prezydent Miasta Sandomierza Onufry Milczarski.

Przybywszy w dniu dzisiejszym do zniesionego klasztoru XX. Dominikanów w Sandomierzu położonego, w obecności delegata ze strony W[ielmożnego] Naczelnika [k. 26v] Wojennego Powiatu Sandomierskiego, Dziekana Dekanatu Sandomierskiego X. Kanonika Goltz i przyzwanego X. Machnickiego b[yłego] Przeora XX. Dominikanów, przystąpili przede wszystkiem do przejrzenia spisu majątku, rzeczonego klasztoru, przy zniesieniu w dniu 15/27 listopada $1864 \mathrm{r}$. i następnych sporządzonego, a porównawszy go ze stanem rzeczy na gruncie znalezionym i ze spisem, który w skutku Instrukcyi Komissyi Rządowej Spraw Wewnętrznych i Duchownych z dnia 5/17 grudnia 1853 był uformowany w dniu 11/23 grudnia 1859 r. osiągnęli przekonanie: że majątek po zniesionym klasztorze XX. Dominikanów w Mieście Sandomierzu znajdującym się pozostały, składa się:

1. Z klasztoru i budowli do niego należących,

2. Z ogrodu i gruntów przy klasztorze położonych,

3. Z placu po dawnym spichlerzu,

4. Z czynszów z placów pod budowle prywatne odstąpionych,

5. Z 1/4 części rybołówstwa na rzece Wiśle i Wisełce,

6. Z inwentarzy i ruchomości tak w samym klasztorze, jak i na folwarkach znajdujących się, [k. 27],

7. Z kapitałów,

8. Z folwarków Gołębice i Jugoszów,

9. Z lasów.

Co do wyszczególnionych wyżej pozycyi, z zebranych wiadomości i dowodów, delegowani następujące domieszczają objaśnienie:

Ad 1. Budowle klasztorne są:

a) Klasztor z cegły murowany o piętrze gontami kryty, długi łokci 85, szerokości łokci 55, wysoki łokci 11, ubezpieczony w Towarzystwie Ogniowem na r[ubli] 2560.

W parterze czyli na dole znajdują się: sień wchodna i korytarz kwadratowy, cela przeorska składająca się z przedpokoju i dwóch małych pokojów po jednem oknie mających;

Refektarz o dwóch oknach połączony drzwiami z celą przeorską;

Kuchnia;

Piwnica;

Spiżarnia o jednem oknie z małą piwniczką.

Skład czyli spichlerz;

Na piętrze korytarz kwadratowy, w którego jednem skrzydle po obu stronach jest jedenaście pokoików po jednem oknie i biblioteka o trzech oknach, inne trzy skrzydła korytarza [k. 27v] są puste bez podłogi i powały z dachem zniszczonym;

b) Stajnia na krowy z chlewikiem na trzodę opasowa, do murów składu czyli spichlerza przyczepiona, $\mathrm{z}$ dwóch boków z drzewa w słupy wystawiona, gontami kryta, długa łokci 8, szerokości łokci 5, wysoka łokci 3.

c) Stajnia na konie naprzeciw poprzedniej z kamienia na wapno murowana gontami kryta, długa łokci 13, szeroka łokci 7, wysoka łokci 5.

d) Wozownia do murów korytarza zachodniego przyczepiona, z kamienia na wapno murowana, gontami kryta, długa łokci 20, szeroka łokci 12, wysoka łokci 5. 
Wymienione wyżej ad b, c, d, budowle stanowią jedną całość z klasztorem, zatem stosownie do $\S 26$ ustępu b Najwyżej zatwierdzonych dodatkowych przepisów o klasztorach, razem z gmachem klasztornym kwalifikują się do pozostawienia przy kościele. Nadmienia się jednak, że wozownia wydzierżawioną została przez przeora tutejszego klasztoru na skład drzewa za opłatą rubli 15, które [k. 28] za rok 1864 dotąd przez dzierżawcę nie zapłacone, uważane być winny jako remanent funduszów klasztoru na zaspokojenie długów pozostałych, i dla tego właściciel drzewa Janchon Spiro zobowiązanym zostaje, aby kwotę powyższą do depozytu Kassy Powiatowej wniósł.

e) Stodoła z drzewa w słupy na przyciesiach wystawiona, słomą kryta, długa łokci 26, szeroka łokci 11, wysoka łokci 5 - o jednym klepisku i dwóch zapolach w stanie dobrym, ubezpieczona od ognia na r[ubli] 70, o łokci 30 od murów klasztoru oddalona, może być razem z przyległymi gruntami wydzierżawioną.

f) Dom mieszkalny przy końcu ogrodu klasztornego położony, od samego klasztoru o 29 prętów odległy, z drzewa w słupy na przyciesiach wystawiony, gontami kryty, długi łokci 20, szeroki łokci 11, wysoki łokci 4, ubezpieczony od ognia na r[ubli] 50, znajduje się w stanie średnim. Składa się z sieni, izby, dwóch małych pokoików, kuchni i spiżarni.

g) Chlewik przy tymże domu z drzewa [k. 28v] w słupy na przyciesiach wystawiony, gontami kryty, długi łokci 9, szeroki łokci 5, wysoki łokci 3, ubezpieczony od ognia na r[ubli] 10, w stanie złym.

Dom ad $\mathrm{f}$ z chlewikiem ad g i kawałkiem ogrodu niżej opisanego około prętów 75 wynoszącym, na mocy umowy między X. Machnickim przeorem dominikańskim a P[anem] Mirosławskim w dniu 3/15 kwietnia 1863 r. zawartej w odpisie dołączonej, wydzierżawiony został temuż P[anu] Mirosławskiemu na lat 3 z dniem 3/15 kwietnia 1866 r. kończące się, za opłatą roczną r[ubli] 30. A że dzierżawca ten wedle pokwitowań na kontrakcie przypadającą od niego należność zapłacił po dzień 15 kwietnia 1864 r. zatem po koniec roku czyli po dzień 15 kwietnia 1865 r. należy się od niego kwota r[ubli] 17 k[opiejek] 50, o której wniesienie do depozytu Kassy Powiatowej tenże obowiązanym zostaje.

Ad 2. Ogrody i grunta $\mathrm{w}$ territorium miasta położone, pomierzone były w roku 1826 razem z miejskiemi przez jeometrę Jarockiego. Podług rejestru [k. 29] pomiarowego z którego wyciąg z rysem odręcznym dołącza się, cała przestrzeń łącznie z placem pod zabudowaniami, wynosi mor[gów] 11 prę[tów] 285, mianowicie:

gruntów ornych mor[gów] 3 pr[ętów] 253

ogrodów warzywnych mor[gów] 2 pr[ętów] 161

pod zabudowaniami mor[gów] 5 pr[ętów] 171

Razem jak wyżej mor[gów] 11 pr[ętów] 285

Lecz takie rozgatunkowanie tej przestrzeni niezgodne jest z miejscowościa gdyż ogród w innem jest położeniu, a przestrzeń mor[gów] 5 pr[ętów] 171, w rejestrze pod pozycyą 231 i 272 w rubryce "pod zabudowaniami” umieszczona, oprócz placu po nieistniejącym już teraz spichlerzu i placu pod zabudowaniami klasztornemi około mor[gi] 1 wynoszącymi, w resztującej obszerności mor[gów] 4 pr[ętów] 171 właściwie stanowi ogród i kawałek gruntu.

Ogród dopiero co wspomniany w 1/4 części owocowy, a 3/4 warzywny przy klasztorze na wschód położony, graniczy od wschodu z domem czynszowym Maryanny Domańskiej i domem wyżej między budowlami klasztornemi pod lit[erą] f wymienionym [k. 29v] tudzież realnościami miejskiemi, od południa z drogą do klasztoru prowadząca, od zachodu z klasztorem, a od północy z parowem za którym jest grunt do Kapituły Katedry Sandomierskiej należący, obejmuje przestrzeń około mor[gów] 4, z których około 75 pr[ętów] wydzierżawione są zarazem z domem po lit[erą] f wyżej wymienionym. Ogród ten stosownie do § 26 ustępu a Najwyżej zatwierdzonych dodatkowych przepisów o klasztorach kwalifikuje się do pozostawienia w używalności duchowieństwa zostającego przy kościele. 
Grunta orne

Rejestr pomiarowy Miasta Sandomierza, z którego wyciąg wyżej dołączony wykazuje:

pod rubryką "ogrody warzywne"

252 za Ś[więtym] Pawłem ${ }^{91}$ mor[ga] 1 pr[ętów] 48

257 na Zawisełczu mor[ga] 1 pr[ętów] 113

Pod rubryką "grunta orne"

270 za Ś[więtym] Pawłem mor[gi] 2 pr[ętów] 44

271 za Ś[więtym] Pawłem mor[ga] 1 pr[ętów] 209

Razem około mor[gów] 6 pr[ętów] 114

Dodając do tego podług domieszczonego wyżej objaśnienia, kawałek gruntu przy dawniejszym [k. 30] z przeniesienia mor[gów] 6 pr[ętów] 114, spichlerzu obecnie nie istniejącym położony, z przestrzeni w rubryce „pod zabudowaniami” poz[ycja] 231 rejestru pomiarowego umieszczonej, wynoszący około pr[ętów] 171. Byłoby zarazem mor[gów] 6 pr[ętów] 285. Co wszystko grunt orny obecnie stanowi.

Lecz że grunt za Ś[więtym] Pawłem pod pozycyą $270 \mathrm{w}$ rejestrze zapisany, wedle oświadczenia X. Machnickiego b[yłego] przeora i zeznania mieszkańców Miasta Sandomierza do oddzielnego protokołu zadyktowanego, nigdy nie był własnością klasztoru, ale należy do probostwa przy kościele Ś[więtego] Pawła, z czego okazuje się, że w mappie i rejestrze dopuszczoną została pomyłka, zatem potrącając mor[gów] 2 pr[ętów] 44 pozostaje gruntów ornych mor[gów] 4 pr[ętów] 241. Ponieważ zaś grunt pod poz[ycją] 271 rejestru pomiarowego, obejmujący mor[gę] 1 pr[ętów] 209 dotyka do murów dzwonnicy, kościoła i klasztoru, i w razie [k. 30v] z przeniesienia mor[gów] 4 pr[ętów] 241 i w razie potrzeby restauracyi tych budowli nie byłoby do nich przystępu i nie byłoby gdzie złożyć materyałów do restauracyi koniecznych, przeto z gruntu tego na powyższy cel, należy pozostawić pr[ętów] 209, a tym sposobem pozostaje do wydzierżawienia mor[gów] 4 pr[ętów] 32.

Grunta te w oddzielnym protokole opisane i dochód $\mathrm{z}$ nich tymczasowo aż do dalszej decyzyi Kommissyi Rządowej Przychodów i Skarbu ustanowiony został na r[ubli] 13 kop[iejek] 42. Nadmienia się jednak, że grunt znajdujący się na Zawisełczu obszerności mor[gi] 1 pr[ętów] 113 obejmujący, podług dołączonej w odpisie umowy w dniu 24 czerwca 1864 r. spisanej wydzierżawiony jest na rok 1 od 1 października 1864 do tegoż dnia 1865 r. za opłatą r[ubli] 4 kop[iejek] 50, już przez X. Machnickiego b[yłego] przeora pobraną.

Ad. 3. Plac po dawnym spichlerzu obecnie nieistniejącym przy drodze do kościoła S. Pawła prowadzącej, obok placu czynszowego Maryanny Kozłowskiej położony, co do powierzchni [k. 31] swej obecnie niewiadomy, może być wieczyście wydzierżawiony.

Ad. 4. Na placach do XX. Dominikanów należących, postawione są trzy domy, mianowicie:

pod n[umerem] 192 Maryanny Domańskiej

pod n[umerem] 6 Ludwika Mazurek

pod n[umerem] 94 Maryanny Kozłowskiej,

pierwszy przy cyplu północno-wschodnim ogrodu warzywnego, dwa drugie przy drodze do Przedmieścia Krakowskiego prowadzącej, obok placu po dawnym spichlerzu dominikańskim. Na place te użytkownicy nie mają żadnych pism lub kontraktów, ani w aktach klasztornych nie ma o nich żadnego śladu, opłacają zaś czynsze każdego roku w czerwcu:

z placu n[umer] $192 \mathrm{k}$ [opiejek] 60

91 Za kościołem parafialnym św. Pawła. 
$\mathrm{z}$ placu n[umer] $6 \mathrm{r}$ [ubli] $1 \mathrm{k}$ [opiejek] 50

$\mathrm{z}$ placu n[umer] $94 \mathrm{r}$ [ubli] 1 k[opiejek] 50

Razem r[ubli] 3 k[opiejek] 60

X. Machnicki b[yły] przeor oświadczył, że po dzień ostatni czerwca 1864 r. z czynszów powyższych zalega u Ludwika Mazurek r[ubli] 1 k[opiejek] 50 a reszta uiszczoną została.

Ad. 5. Na zasadzie decyzji byłego rządu Gubernialnego Sandomierskiego z dnia 18/30 marca 1838 r. n[umer] 13942 [k. 31v] klasztor XX. Dominikanów w Sandomierzu ma prawo do 1/4 części dochodu pobieranego przez Kassę Miejską z dzierżawy rybołówstwa na rzece Wiśle i Wisełce.

Podług poświadczenia Kassy Miasta Sandomierza pod dniem 2/14 stycznia 1865 r. n[umer] 2 udzielonego - na zasadzie ksiąg Kassowych, dochód w mowie będący wydzierżawiony jest na czas od 1 stycznia 1864 r. po koniec grudnia 1866 r. za opłatą roczną do Kassy Miejskiej wpływającą w wysokości r[ubli] 100 k[opiejek] 10. Do tego więc dochodu przypada klasztorowi rocznie r[ubli] 25 k[opiejek] 2 1/2, na rachunek których za rok 1864 wypłacono przeorowi X. Machnickiemu r[ubli] 12 k[opiejek] 12, a należy jeszcze do wypłaty r[ubli] 12 k[opiejek] 52 1/2.

Ad. 6. Inwentarz żywy, jaki na folwarkach Gołębice i Jugoszów znajduje się jako to: koni 10, wołów 8, krów 11, jałowizny sztuk 7, owiec 2 i jagniąt 30, jak również inwentarz martwy, czyli różne sprzęty i narzędzia rolnicze, pozostawione są na tychże folwarkach do użytku gruntowego. Podług dopełnionego oszacowania wartość ich wynosi:

na folwarku Gołębice r[ubli] 440 k[opiejek] 89

na folwarku Jugoszów r[ubli] 356 k[opiejek] 63

Razem r[ubli] 797 k[opiejek] 62

[k. 32] Prócz tego była na folwarkach trzoda i drób, które przez licytacyą publiczną w Sandomierzu w dniu 8/20 stycznia 1865 r. odbytą sprzedane zostały za r[ubli] 89 kop[iejek] 58. Z ruchomości zaś i sprzętów w klasztorze znajdujących się, pozostawiono do użytku X. Tymoteusza Jaskulskiego dominika[ni]na, sprzęty załączonym wykazem objęte na r[ubli] 31 kop[iejek] 82 oszacowane, resztę zaś przez licytacyą publiczną w dniu 31 grudnia/12 stycznia 1864/5 r. odbytą sprzedano za r[ubli] 106 kop[iejek] 73. Sprzedane również zostały z r[ubli] 90 dwa wieprze tuczone w klasztorze przy zamknięciu go będące.

Nadmienia się jednak, że pomiędzy inwentarzem żywem wyżej okazanym na folwarku Jugoszów znajdują się dwie jałówki podług zeznania ludzi miejscowych, stanowiące osobistą własność X. Machnickiego b[yłego] przeora XX. Dominikanów sandomierskich, po które on przez podanie z dnia 3/15 stycznia 1865 r. zgłosił się. Jakkolwiek zaś $\S 42$ przepisów dodatkowych do Najwyższego Ukazu z d[nia] 27/8 października/listopada 1864 r. wyłącza spod zajęcia w zawiadywanie Skarbu osobisty majątek zakonników, przecież delegowani [k. 32v] wydanie rzeczonych jałówek decyzyi władzy pozostawiają.

Ad. 7. Podług spisu majątku XX. Dominikanów w Sandomierzu w roku 1859 sporządzonego, kapitały stanowiące własność tego klasztoru wynoszą r[ubli] 6953 k[opiejek] 40. Do tego stosownie do Reskryptu Rządu Gubernialnego z dnia 16/28 września 1864 roku n[umer] 36398 przybył kapitał w Lustracyi z r. 1819 między niepewnemi zamieszczony, a teraz z dóbr Pisary spłacony r[ubli] 30. W ogóle r[ubli] 6985 k[opiejek] 40.

A że wedle dołączonego Wykazu Banku z dnia 1 października 1862 r. znajduje się tamże na lokacyi r[ubli] 6293 k[opiejek] 40 i zapewne odesłano tamże powyższy kapitał z dóbr Pisary r[ubli] 30. Razem r[ubli] 6323 k[opiejek] 40. Zatem pozostaje na hipotekach r[ubli] 660 [k. 33] mianowicie:

a) na dobrach Strzyżowice r[ubli] 150

b) na dobrach Przyborowice r[ubli] 112 k[opiejek] 50

c) na folwarku Kobierniki Krzesimowskiego r[ubli] 52 k[opiejek] 50 
d) na folwarku Kobierniki Gajewicza r[ubli] 15

e) na folwarku Chwałki r[ubli] 60

f) na domu w Sandomierzu Stanisławskich r[ubli] 75

g) na domu w Sandomierzu Dutreppiego r[ubli] 67 k[opiejek] 50

h) na domu w Sandomierzu Jordana r[ubli] 45

i) na domu w Sandomierzu Dziarskiego r[ubli] 7 k[opiejek] 50

j) na domu w Sandomierzu Rogowskiego r[ubli] 15

k) na domu w Sandomierzu Szefera v[el] Szlamy Kandel r[ubli] 45

1) na gruntach Branickich r[ubli] 15

Razem jak wyżej r[ubli] 660

X. Machnicki b[yły] przeor XX. Dominikanów w Sandomierzu objaśnił, że procent od kapitału na dobrach Strzyżowice lokowanego, płaconym bywa po 5\% z dniem ostatnim grudnia każdego roku, i że z końcem roku 1864 zalega za lat trzy po r[ubli] 7 k[opiejek] 50 czyli r[ubli] 22 k[opiejek] 50. Kapitał zaś 15 na gruntach Branickich w Sandomierzu nie był hipotekowany, i procent od dawna nie jest pobierany. Katarzyna 1 voto Branicka 2 Kowalska grunta swoje posprzedawała i lat kilkanaście temu umarła. Zapisu i żadnego dokumentu na ten kapitał nie ma w aktach klasztornych. Od reszty kapitałów hipotekowanych [k. 33v] procenta są regularnie uiszczane po 5 \% na Ś[więt]y Jan Chrzciciel, czyli w miesiącu czerwcu, i po ten dzień 1864 r. opłacone zostały.

Ad. 8. Do klasztoru XX. Dominikanów sandomierskich należą dwa folwarki: Gołębice o wiorst 2, i Jugoszów o mil 2 od Sandomierza odległe. Podług wysiewu rozległość ich w gruntach i ogrodach wynosi:

folwarku Gołębice około mor[gów] 202 (po odtrąceniu gruntów na 12 korcy wysiewu, danych w r. 1863 dwom włościanom z niwy dworskiej)

folwarku Jugoszów około mor[gów] 232

Razem około mor[gów] 434.

Oprócz łąk z których zbiera się siana z potrawem

na folwarku Gołębice 8-cetnarowych fur 6

na folwarku Jugoszów 6-cetnarowych fur 36

Razem fur 42.

Folwarki te w oddzielnie sporządzonej Lustracyi opisane, i dochód z nich tymczasowo aż do dalszej decyzyi Komissyi Rządowej Przychodów i Skarbu ustanowiony został:

z folwarku Gołębice na r[ubli] 281 k[opiejek] 60

z folwarku Jugoszów na r[ubli] 244 k[opiejek] 75

razem na r[ubli] $526 \mathrm{k}$ [opiejek] 35

[k. 34] wyjąwszy dochodu z propinacyi we wsi Jugoszów, który podług kontraktu zawartego w dniu 25 maja 1864 r. między przeorem XX. Dominikanów a P[anem] Hennel właścicielem dóbr Bilcza od 12/24 czerwca 1864 r. czyni rocznie kwotę r[ubli] 75, a po odtrąceniu opłaty na indemnizacyą ${ }^{92} \mathrm{r}$ [ubli] $36 \mathrm{w}$ resztującej ilości wynosi r[ubli] 39.

Na poczet należności za rok 1864/5 w ilości r[ubli] 75. X. Machnicki b[yły] przeor odebrał r[ubli] 46 k[opiejek] 25. Pozostaje zaś u P[ana] Hennel r[ubli] 28 k[opiejek] 75.

Propinacya we wsi Gołębice z Sucharzowem, na mocy wyroku Komissyów Rządowych Wyznań Religijnych i Oświecenia Publicznego, tudzież Spraw Wewnętrznych i Policyi w dniu 1 listopada 1824 r. zapadłego, należy do Miasta Sandomierza.

Nadmienia się przy tem, że do wspomnionych wyżej folwarków należały wsie Gołębice z Sucharzowem i Jugoszów, z których prestanda podług tabel w roku 1846 zatwierdzonych wynosiły:

92 Indemnizacja - odszkodowanie dla właścicieli ziemskich płacone w związku z uwłaszczeniem chłopów w postaci łzw. podatku indemnizacyjnego. 
z wsi Gołębice z Sucharzowem dni pieszych 2528

z wsi Jugoszów dni sprzężajnych 416, pieszych 2132, czynsiku kop[iejek] 15 [k. 34v], kapłonów 4 i jaj sztuk 30. Lecz włościanie na mocy ukazu Najwyższego z dnia 19/2 lutego/marca 1864 r. uwłaszczeni, od wszelkich powinności dworskich uwolnieni zostali.

Folwarki w mowie będące, jako od siebie o mil 2 odległe, kwalifikują się do oddzielnego wydzierżawienia. Przy folwarku Gołębice znajduje się lasek dębowy i sosnowy mor[gów] 63 pr[ętów] 80. Zaś przy folwarku Jugoszów lasek grabowy mor[gów] 8 pr[ętów] 80. Razem mor[gów] 71 pr[ętów] 160.

Laski te już od dawna zostają w adminstracyi Rządu pod nadzorem Urzędu Leśnego Łagów, i obecnie żadne cięcia ich nie mają miejsca.

Podatki i ciężary, jakie z opisanych wyżej realności przypadają są następujące:

A. z realności w Mieście Sandomierzu do Kassy Miejskiej

\begin{tabular}{|l|c|c|c|c|}
\hline \multirow{2}{*}{} & \multicolumn{2}{|c|}{ W szczególe } & \multicolumn{2}{c|}{ W ogóle } \\
\cline { 2 - 5 } & $\mathrm{r}[\mathrm{uble}]$ & $\mathrm{k}[\mathrm{opiejki]}$ & $\mathrm{r}$ [uble] & k[opiejki] \\
\hline Z gruntów liwerunku* & 1 & 6 & & \\
\hline Z kościoła i klasztoru składki ogniowej & 30 & 13 & & \\
\hline Z domu podymnego & 4 & & & \\
\hline Składki ogniowej & & 36 & & \\
\hline Składki kwaterunkowej & & 54 & & \\
\hline Składki transportowej & & 36 & & \\
\hline Składki szkolnej & & $371 / 2$ & & \\
\hline [k. 35] z przeniesienia & & & 36 & $821 / 2$ \\
\hline Do Kassy Powiatowej ofiary & 9 & $31 / 2$ & & \\
\hline Subsidium ${ }^{* *}$ & 3 & & & \\
\hline & & & 12 & $31 / 2$ \\
\hline $\begin{array}{l}\text { Do kościoła [św.] Pawła w Sandomierzu } \\
\text { dziesięciny żyta korzec 1 garncy 10, } \\
\text { licząc po r[ublu] 1 k[opiejek] 50 }\end{array}$ & & & & \\
\hline Razem & & & 50 & 83 \\
\hline
\end{tabular}

* Liwerunek - podatek na utrzymanie wojska; ** Subsidium charitativum - w XIX wieku był to podatek gruntowy płacony z dóbr należących do duchowieństwa.

B. z folwarku Gołębice

\begin{tabular}{|l|c|c|c|c|}
\hline \multirow{2}{*}{} & \multicolumn{2}{|c|}{ W szczególe } & \multicolumn{2}{c|}{ W ogóle } \\
\cline { 2 - 5 } & $\mathrm{r}[\mathrm{uble}]$ & $\mathrm{k}[$ opiejki] & $\mathrm{r}[\mathrm{uble}]$ & $\mathrm{k}$ [opiejki] \\
\hline Ofiary & 29 & 41 & & \\
\hline Liwerunku dawnego & 22 & 39 & & \\
\hline Liwerunku dodatkowego & 22 & 39 & & \\
\hline Podymnego & 8 & & & \\
\hline Na drogi boczne & & 80 & & \\
\hline Składki ogniowej & 4 & $71 / 2$ & & \\
\hline
\end{tabular}




\begin{tabular}{|l|c|c|c|c|}
\hline Składki szkolnej do Kassy Miejskiej & 1 & 20 & & \\
\hline Na wójta gminy & 14 & & & \\
\hline $\begin{array}{l}\text { Dziesięciny do kapituły katedry san- } \\
\text { domierskiej żyta korcy 19 gar[ncy] }\end{array}$ & 29 & $551 / 2$ & & \\
227, licząc po r[ublu] 1 k[opiejek] 50 & & & 131 & 82 \\
\hline Razem & & & \\
\hline
\end{tabular}

C. z folwarku Jugoszów

\begin{tabular}{|l|c|c|c|c|}
\hline & \multicolumn{2}{|c|}{ W szczególe } & \multicolumn{2}{c|}{ W ogóle } \\
\hline & $\mathrm{r}[\mathrm{uble}]$ & $\mathrm{k}[\mathrm{opiejki}]$ & $\mathrm{r}[\mathrm{uble}]$ & $\mathrm{k}$ [opiejki] \\
\hline Ofiary & 20 & 6 & & \\
\hline Subsidium & 15 & & & \\
\hline Liwerunku dawnego & 36 & $921 / 2$ & & \\
\hline Liwerunku dodatkowego & 36 & $921 / 2$ & & \\
\hline Podymnego & 8 & & & \\
\hline Na drogi boczne & 1 & 80 & & \\
\hline [k. 35v] z przeniesienia & & & 182 & 65 \\
\hline Opłaty z propinacyi & 36 & & & \\
\hline Składki ogniowej & 6 & 84 & & \\
\hline Na wójta gminy & 35 & & & \\
\hline $\begin{array}{l}\text { Dziesięciny do kościoła w Goźlicach żyta } \\
\text { korcy 12, licząc po r[ublu] 1 k[opiejek] 50 }\end{array}$ & 18 & & & \\
\hline Razem & & & 214 & 55 \\
\hline
\end{tabular}

W ogóle podatki i ciężary z realności klasztornych wynoszą r[ubli] 397 kop[iejek] 20. Zaległości podatków i ciężarów z realności klasztornych są:

Podług wykazu Kassy Miasta Sandomierza

\begin{tabular}{|l|c|c|c|c|}
\hline \multirow{2}{*}{} & \multicolumn{2}{|c|}{ W szczególe } & \multicolumn{2}{c|}{ W ogóle } \\
\cline { 2 - 5 } & r[uble] & k[opiejki] & r[uble] & k[opiejki] \\
\hline $\begin{array}{l}\text { Z kościoła i zabudowań klasztornych } \\
\text { składka ogniowa za półrocze II 1862 r. } \\
\text { i I półrocze 1863 r. }\end{array}$ & 21 & 70 & & \\
\hline $\begin{array}{l}\text { Z kościoła i zabudowań klasztornych } \\
\text { składka ogniowa za półrocze II 1863 r. }\end{array}$ & 18 & 8 & & \\
\hline $\begin{array}{l}\text { Z kościoła i zabudowań klasztornych } \\
\text { składka ogniowa za półrocze I 1864 r. }\end{array}$ & 12 & 5 & & \\
\hline $\begin{array}{l}\text { Z domu klasztornego składka ognio- } \\
\text { wa za półrocze I 1864 r. }\end{array}$ & & 18 & & \\
\hline Składka kwaterunkowa za rok 1864 & & 54 & & \\
\hline Razem & & & 52 & 55 \\
\hline
\end{tabular}


Podług wykazu Kassy Powiatu Sandomierskiego z folwarku Gołębice

\begin{tabular}{|l|c|c|c|c|}
\hline \multirow{2}{*}{} & \multicolumn{2}{|c|}{ W szczególe } & \multicolumn{2}{c|}{ W ogóle } \\
\cline { 2 - 5 } & r[uble] & k[opiejki] & r[uble] & k[opiejki] \\
\hline Opłata za bydło za r. 1864 & 3 & 90 & & \\
\hline Składka ogniowa za rok 1863 & 2 & 36 & & \\
\hline Kary egzekucyjne z lat 1855/63 & 61 & $321 / 2$ & & \\
\hline Razem & & & 67 & $1 / 2$ \\
\hline
\end{tabular}

[k. 36] Z folwarku Jugoszów

\begin{tabular}{|l|c|c|c|c|}
\hline & \multicolumn{2}{|c|}{ W szczególe } & \multicolumn{2}{c|}{ W ogóle } \\
\hline Opłata z propinacyi z r. 1864 & r[uble] & k[opiejki] & r[uble] & k[opiejki] \\
\hline Opłata za bydło z r. 1863 & 18 & & & \\
\hline Składka ogniowa z r. 1863 & 2 & 70 & & \\
\hline Kary egzekucyjne z lat 1855/63 & 75 & 84 & & \\
\hline Razem & & & 103 & $1 / 2$ \\
\hline
\end{tabular}

Podług odezwy proboszczów kapituły katedry sandomierskiej zalega za r. 1864 dziesięcina wyżej pod ciężarami wykazana w ilości żyta kor[cy] 33 gar[ncy] 1/2 wartości po r[ublu] 1 k[opiejek] 50 za korzec, r[ubli] 49 k[opiejki] 52 1/2.

Wedle podań wójtów gmin należy się im składka mianowicie:

Wójtowi Gminy Kamień Mściowski z folwarku Gołębice po dzień 3/15 stycznia 1865 r. r[ubli] 3 k[opiejek] 50

Wójtowi Gminy Święcica z folwarku Jugoszów po koniec lutego 1865 r. r[ubli] 17 $\mathrm{k}$ [opiejek] 50

Wreszcie Małgorzacie Brozman utrzymującej służbę kominiarską w Sandomierzu, za wycieranie kominów w klasztorze za kwartał IV 1864 roku r[ubel] 1.

W ogóle podatki i ciężary z czasu po koniec 1864 r. zalegają w sumnie r[ubli] 295 k[opiejki] 29.

Podług oddzielnie spisanych protokołów należy się: [k. 36v]

\begin{tabular}{|c|c|c|c|c|c|}
\hline & & \multicolumn{2}{|c|}{ W szczególe } & \multicolumn{2}{|c|}{ W ogóle } \\
\hline & & $\mathrm{r}[\mathrm{uble}]$ & k[opiejki] & r[uble] & $\mathrm{k}$ [opiejki] \\
\hline \multirow{2}{*}{$\begin{array}{l}\text { Opłata dla } \\
\text { służby }\end{array}$} & z folwarku Gołębice i z klasztoru & 80 & 50 & & \\
\hline & z folwarku Jugoszów & 65 & 10 & 147 (sic!) & 60 \\
\hline \multirow{3}{*}{$\begin{array}{l}\text { Za najem } \\
\text { robót } \\
\text { gospodar- } \\
\text { skich }\end{array}$} & Włościanom wsi Gołębice & 21 & $771 / 2$ & & \\
\hline & Włościanom wsi Jugoszów & 119 & $821 / 2$ & & \\
\hline & $\begin{array}{l}\text { Oraz ekonomowi za wydatki na } \\
\text { najem i inne potrzeby gospo- } \\
\text { darskie }\end{array}$ & 120 & $651 / 2$ & & \\
\hline Razem & & & & 262 & $251 / 2$ \\
\hline
\end{tabular}


Długi prywatne, majątek XX. Dominikanów sandomierskich obciążające, z jakiemi wierzyciele wystąpili, są następujące:

\begin{tabular}{|c|c|c|c|c|c|}
\hline & \multicolumn{2}{|c|}{ W szczególe } & \multicolumn{2}{|c|}{ W ogóle } \\
\hline & & r[uble] & k[opiejki] & r[uble] & k[opiejki] \\
\hline 1. & $\begin{array}{l}\text { Ewarystowi Rutkowskiemu i Kajetanowi } \\
\text { Kwitek klerykom XX. Dominikanów na } \\
\text { ubiór zakonny za rok } 1864 \text { wedle podania } \\
\text { tychże z dnia } 19 / 31 \text { stycznia } 1865 \text { r. każde- } \\
\text { mu po r[ubli] } 15\end{array}$ & 30 & & & \\
\hline 2. & $\begin{array}{l}\text { X. Tymoteuszowi Jaskulskiemu dominika- } \\
\text { [ni]nowi wedle podania z d[nia] } 15 \text { lutego } \\
1865 \mathrm{r} \text {. }\end{array}$ & 35 & 40 & & \\
\hline 3. & $\begin{array}{l}\text { X. Alfonsowi Kolińskiemu dominika[ni] } \\
\text { nowi podług rewersu z dnia } 11 \text { stycznia } \\
1865 \text { roku }\end{array}$ & 17 & 25 & & \\
\hline 4. & $\begin{array}{l}\text { Berkowi Las bednarzowi z Sandomierza } \\
\text { podług rewersu z dnia } 15 \text { listopada } 1864 \text { r. }\end{array}$ & 6 & & & \\
\hline & [k. 37] z przeniesienia & & & 88 & 65 \\
\hline 5. & $\begin{array}{l}\text { Mortce Manchajm rzeźnikowi z Sandomie- } \\
\text { rza podług podania z d[nia] 15/27 grudnia } \\
1864 \text { i dopełnionego podaniem 8/20 lutego } \\
1865 \text { r. obrachunku czyli rewersu }\end{array}$ & 33 & $561 / 2$ & & \\
\hline 6. & $\begin{array}{l}\text { Moritrzowi, Sejdel i spółce kupcom z War- } \\
\text { szawy podług rachunku z d[nia] } 29 \text { grudnia } \\
1864 \text { r. }\end{array}$ & 76 & 50 & & \\
\hline 7. & $\begin{array}{l}\text { Dutreppiemu kupcowi z Sandomierza po- } \\
\text { dług rachunku z d[nia] 9/21 stycznia } 1865 \text { r. }\end{array}$ & 8 & 76 & & \\
\hline 8. & $\begin{array}{l}\text { Jakubowi Czmielewskiemu z Sandomierza } \\
\text { podług rewersu z d[nia] } 25 \text { listopada } 1864 \mathrm{r} \text {. }\end{array}$ & 15 & & & \\
\hline 9. & $\begin{array}{l}\text { Mateuszowi Józefowicz z Sandomierza po- } \\
\text { dług obrachunku z dnia } 20 \text { września } 1864 \text { r. } \\
\text { za roboty malarskie r[ubli] } 38 \text { k[opiejek] } 60 \\
\text { i podług rewersu z d[nia] } 22 \text { grudnia } 1862 \\
\text { r[ubli] } 30\end{array}$ & 68 & 60 & & \\
\hline 10. & $\begin{array}{l}\text { Nucie Lubelskiemu z Sandomierza podług } \\
\text { rewersu z dnia } 1 \text { października } 1864 \text { r. }\end{array}$ & 28 & 32 & & \\
\hline 11. & $\begin{array}{l}\text { Ickowi Rużanemu z Sandomierza podług } \\
\text { dwóch rewersów z dnia } 3 \text { i } 25 \text { listopada } \\
1864 \text { r. }\end{array}$ & 37 & 50 & & \\
\hline 12. & $\begin{array}{l}\text { Mortce Fingiryt z Sandomierza podług } \\
\text { czterech rewersików z d[nia] } 12 \text { września, } 2 \\
\text { października, [k. 37v] } 8 \text { i } 27 \text { listopada } 1864 \text { r. }\end{array}$ & 37 & 10 & & \\
\hline 13. & $\begin{array}{l}\text { Szymonowi Opatowskiemu z Sandmierza } \\
\text { podług umowy z dnia } 25 \text { grudnia } 1863 \text { r. za } \\
\text { opłatą konsumcyjną }\end{array}$ & 10 & 50 & & \\
\hline
\end{tabular}




\begin{tabular}{|c|c|c|c|}
\hline 14. & $\begin{array}{l}\text { Zelmanowi Tenenbaum szklarzowi z San- } \\
\text { domierza ustnie zgłaszającemu się za wpra- } \\
\text { wienie } 10 \text { szyb po k[opiejek] } 15\end{array}$ & 1 & 50 \\
\hline 15. & $\begin{array}{l}\text { Szlamie Kandel z Sandomierza podług } \\
\text { rewersu z dnia } 10 \text { października } 1864 \text { r. }\end{array}$ & 293 & $371 / 2$ \\
\hline 16. & $\begin{array}{l}\text { Juliowi Kandel z Sandomierza podług } \\
\text { rewersu z d[nia] } 21 \text { stycznia } 1864 \text { r. }\end{array}$ & 24 & 75 \\
\hline 17. & $\begin{array}{l}\text { Lejbusiowi Spiro z Sandomierza podług } \\
\text { rewersu z dnia } 10 \text { października } 1864 \text { r. }\end{array}$ & 168 & $681 / 2$ \\
\hline \multirow[t]{2}{*}{18.} & $\begin{array}{l}\text { Janklowi Frydman z Sandomierza podług } \\
\text { rachunku z dnia } 5 \text { listopada } 1864 \text { roku }\end{array}$ & 24 & 21 \\
\hline & Razem & 917 & 2 \\
\hline
\end{tabular}

Zebrane razem zaległości skarbowe z długami ekonomicznemi i prywatnemi czynią:

\begin{tabular}{|l|c|c|}
\hline & \multicolumn{2}{|c|}{ W szczególe } \\
\hline & $\mathrm{r}[\mathrm{uble}]$ & $\mathrm{k}$ [opiejki] \\
\hline Z podatków i ciężarów gruntowych & 295 & 27 \\
\hline Dla służby ekonomicznej & 147 & 60 \\
\hline Za najem i potrzeby gospodarskie & 262 & $251 / 2$ \\
\hline Długi prywatne & 917 & 2 \\
\hline W ogóle & 1621 & 90 \\
\hline
\end{tabular}

Nadto handlarze z Miasta Sandomierza wystąpili z żądaniem wydania im sprzedanego [k. 38] przez X. Machnickiego b[yłego] przeora i już zapłaconego zboża jako to:

Icek Różany pszenicy kor[cy] 61 i prosa korcy 10

Boruch Cukerblum pszenicy korcy 9 i żyta kor[cy] 14

które to żądanie do decyzyi Rządu przedstawione zostało.

Obecny powyższej czynności X. Machnicki b[yły] przeor XX. Dominikanów sandomierskich oświadczył: że na rachunek powyższych zaległości i długów nic nikomu dotąd nie wypłacił, że takowe są rzetelne, oraz że nie ma żadnych wzajemnych z funduszów klasztornych pochodzących pretensyi do swoich wierzycieli ani też do nikogo innego prócz objętych niniejszym protokołem. Należy się tylko klasztorowi za utrzymywanie dwóch demerytów z klasztoru na Łysej Górze przeniesionych, przez czas od 1 maja do włącznie 15/27 listopada 1864, czyli za dni 211, podług podanych za pośrednictwem Konsystorza likwidacyi r[ubli] 182 k[opiejek] 38.

Obok tego wzmiankowany przeor prosi, aby kary exekucyjne kwot r[ubli] 137 kop[iejek] 15 wynoszące, umorzone zostały, gdyż to wynikły jedynie z [k. 38v] powodu rzeczywistej niemożności uiszczenia w właściwym czasie należności skarbowych.

Na satysfakcyą wykazanych wyżej zaległości i długów, znajdują się fundusze protokołem niniejszym wykazane, to jest:

a) Za skład drzewa od Janchona Spiry za rok 1864 r[ubli] 15

b) Z wydzierżawionego domu w Sandomierzu od Mirosławskiego r[ubli] 17 k[opiejek] 50

c) Czynsz od Ludwika Mazurek r[ubli] 1 k[opiejek] 50

d) Z rybołówstwa od Kassy Miejskiej r[ubli] 12 k[opiejek] 52 1/2 
e) Ze sprzedaży ruchomości, trzody, drobiu i wieprzów tuczonych r[ubli] 286 k[opiejek] 31

f) Zaległy od właściciela dóbr Strzyżowice procent r[ubli] 22 k[opiejek] 50

g) Z dzierżawy propinacyi w Jugoszowie r[ubli] $28 \mathrm{k}$ [opiejek] 75

h) Za utrzymanie demerytów r[ubli] 182 k[opiejek] 38

Razem r[ubli] 566 k[opiejek] 46 1/2

Prócz tego za sprzedane remanenta zbożowe osiągnie to r[ubli] 528 k[opiejek] 9

W ogóle r[ubli] 1094 kop[iejek] 55 1/2

Lecz że z tego a mianowicie z funduszu za sprzedane ruchomości, trzodę i zboże zapłacono na rachunek podatków i ciężarów. [k. 39] jek] 80,

Zaległą składkę ogniową i opłatę od bydła do Kassy Powiatowej r[ubli] 15 k[opie-

Wójtom Gmin r[ubli] 21

Za wycieranie kominów w kwartale IV 1864 r. r[ubel] 1

Służbie folwarcznej i klasztornej r[ubli] 147 k[opiejek] 60

Łącznie zapłacono na zaległości r[ubli] 185 k[opiejek] 40

Na podatki z raty I 1865 r. do Kassy Powiatowej r[ubli] 123 k[opiejek] 1 1/2

$\mathrm{Na}$ administracyą od 16/28 listopada 1864 r. wydano i do 1 czerwca 1865 r. potrzeba wydać r[ubli] 340 k[opiejek] 18 1/2

Razem r[ubli] 648 k[opiejek] 60

Pozostaje więc funduszu r[ubli] 445 k[opiejek] 95 1/2

Mianowicie w gotowiźnie wniesionej do depozytu Kassy Powiatowej r[ubli] 165 k[opiejek] 80 a reszta r[ubli] 280 k[opiejek] 15 1/2 stanowi należność do uzyskania.

Rezultat

Zaległości z długami wynoszą summę r[ubli] 1621 k[opiejek] 90

Na rachunek tego zapłacono r[ubli] 185 k[opiejek] 40

Pozostaje r[ubli] 1436 k[opiejek] 50

[k. 39v] A że dotychczasowe fundusze wynoszą:

w gotowiźnie wniesionej do Kassy Powiatowej r[ubli] 165 k[opiejek] 80

w należności do odzyskania r[ubli] 280 k[opiejek] 15 1/2

łącznie r[ubli] 445 k[opiejek] 95 1/2

przeto zostaje długu r[ubli] 990 k[opiejek] 54 1/2

Jednakże, ponieważ dziesięcinę duchowieństwu przypadającą w ilości żyto korcy 33 gar[ncy] 1/2 liczono podług cen normalnych anszlagowych ${ }^{93}$ po r[ublu] 1 k[opiejek] 50 a takowe, z powodu że nie było gdzie mieścić na folwarku, sprzedano korzec po r[ubli] 2 k[opiejek] 71 i gotowiznę za nie otrzymaną wliczono do ogólnych funduszów w pośród summy r[ubli] 528 kop[iejek] 9, zatem rachując przewyżki na korcu po r[ublu] 1 kop[iejek] 21, dług zwiększa się o r[ubli] 39 k[opiejek] 97 i wynosi w ogóle r[ubli] 1030 k[opiejek] 51 1/2.

Wykazany wyżej majątek [k. 40] po zniesionym klasztorze XX. Dominikanów w Sandomierzu pozostały, delegowani przyjmują w administracyą Skarbu, i akt niniejszy w trzech exemplarzach sporządzony, wspólnie z attentującemi osobami podpisują

X. Paulin Machnicki były przeor XX. Dominikanów

w obecności mojej jako assystującego czynności X. Saturnin Goltz

Prezydent Miasta Sandomierza Milczarski

Assessor Ekonomiczny A. Jurkowski

Źródło: Archiwum Państwowe w Radomiu, Zarząd Rolnictwa i Dóbr Państwowych Guberni Radomskiej, Kieleckiej, Lubelskiej, Siedleckiej, Sukcesje, sygn. 9601, k. 26-40.

93 Anszlag - kosztorys, wykaz kosztów. 


\section{REFERENCES (BIBLIOGRAFIA)}

\section{Archival sources (Źródła archiwalne)}

Archiwum Diecezjalne w Sandomierzu:

Akta Konsystorza Jeneralnego Dyecezyi Sandomierskiej ts. stanu wojennego.

Dominikanie Klimontów 1844-1871.

Dominikanie Sandomierz 1845-1867.

Ks. Kajetan Kwitek 1867-1922.

Archiwum kościoła św. Jakuba w Sandomierzu:

Książka Różańca Ś. Przy kościele ś. Jakuba w Sandomierzu.

Archiwum Państwowe w Radomiu:

Izba Skarbowa Radomska, sygn. 281.

Rząd Gubernialny Radomski, sygn. 4264, 4265, 5040.

Wydział Gospodarczy gr. II, sygn. 665.

Zarząd Rolnictwa i Dóbr Państwowych Guberni Radomskiej, Kieleckiej, Lubelskiej, Siedleckiej, Sukcesje, sygn. 9601, 9602.

\section{Printed sources (Źródła drukowane)}

Catalogus Conventuum juxta Ordinem Antiquitatis, cum Specifica expressione Religiosorum ac Monialium, Provinciae Polonae S. Ordinis Praedicatorum in Annum 1847, [b.d.m.w.].

Catalogus Conventuum juxta Ordinem Antiquitatis, cum Specifica expressione Religiosorum ac Monialium, Provinciae Polonae S. Ordinis Praedicatorum in Annum 1851, [b.d.m.w.].

Catalogus cum specifica expressione Religiosorum ac Monialium Provinciae Polonae S. Hyacinthi Ordinis Praedicatorum, in Annum 1837, [b.d.m.w.].

Directorium Officii Divini juxta rubricas breviarii ritumque missalis Sacri Ordinis Praedicatorum pro Polona Provincia S. Hyacinthi C.P.R.P. in annum Domini MDCCCLXI, Varsaviae 1861.

Directorium Officii Divini juxta rubricas breviarii ritumque missalis Sacri Ordinis Praedicatorum pro Polona Provincia S. Hyacinthi C.P.R.P. in annum Domini MDCCCLXII, Varsaviae 1862.

Directorium Officii Divini juxta rubricas breviarii ritumque missalis Sacri Ordinis Praedicatorum pro Polona Provincia S. Hyacinthi C.P.R.P. in annum Domini 1869, [b.m.d.w.].

Catalogus Patrum et Fratrum ac Monialium Sacri Ordinis Praedicatorum Provinciae Poloniae in annum 1859 conscriptus, [b.d.m.w.].

Schematismus Patrum et Fratrum bec non Monialium S. Ordinis Praedicatorum provinciae St. Hyacinthi, in regno Galiciae austriacae et M.D. Cracoviensi pro anno 1875, Cracoviae 1875.

\section{Studies (Opracowania)}

Buliński M., Monografija miasta Sandomierza, Warszawa 1879.

Burdzy D., Biblioteka dominikańskiego klasztoru św. Jakuba Apostoła w Sandomierzu w świetle katalogu z 1860 r., w: Arma nostrae militiae. Kultura ksiażki i pisma Zakonu Kaznodziejskiego na ziemiach polskich, red. I. Pietrzkiewicz, M. Miławicki, Poznań 2019.

Burdzy D., "O wypadkach zaszłych w mieście Sandomierzu”. Dominikanie z klasztoru przy kościele św. Jakuba w przededniu powstania styczniowego, w: Historia magistra vitae est... Studia z dziejów społeczno-politycznych, gospodarczych i kulturalnych. Księga jubileuszowa dedykowana prof. zw. dr. hab. Wiestawowi Cabanowi z okazji 45-lecia pracy naukowej, red. L. Michalska-Bracha, M. Przeniosło, B. Wojciechowska, Kielce 2016.

Gach P.P., Kasaty zakonów na ziemiach polskich dawnej Rzeczypospolitej i Ślaska 1773-1914, Lublin 1984. 
Gach P.P., Le soppressioni dei Regolari (1773-1914) nella cartografia e nella recente storiografia polacca, in: Le inchieste Europee sui beni ecclesiastici (confronti regionali secc. XVI-XIX), red. G. Poli, Bari 2005.

Gach P.P., Mienie polskich zakonów i jego losy w XIX wieku, Rzym 1979.

Gach P.P., Struktury i działalność duszpasterska zakonów męskich na ziemiach dawnej Rzeczypospolitej i Ślaska w latach 1773-1914, Lublin 1999.

Gach P.P., Zakony w diecezji kieleckiej 1905-1914, „Nasza Przeszłość” 1983, 59.

Gach P.P., Zakony w Europie Środkowo-Wschodniej (1773-1914), w: Zakony i klasztory w Europie Środkowo-Wschodniej X-XX wiek. Materiały z międzynarodowego seminarium pt. Atlas ruchu zakonnego w Europie Środkowo-Wschodniej X-XX wiek. Lublin, 25-27 listopada 1993, red. H. Gapski, J. Kłoczowski, Lublin 1999.

Gajewski S., Kasata klasztorów w diecezji lubelskiej w roku 1864, „Roczniki Humanistyczne” 1973, 21, 2.

Gajewski S., Ostatnie klasztory diecezji lubelskiej w XIX wieku, „Roczniki Humanistyczne” $1974,22,2$.

Gajewski S., Własność poklasztorna w diecezji lubelskiej w II poł. XIX wieku, „Roczniki Humanistyczne" 1975, 23, 2.

Jabłońska-Deptuła E., Dominikańska opozycja. Przyczynek do społecznego charakteru bractw w połowie XIX w., „W Drodze” 1973, 1, 3-4.

Jabłońska-Deptuła E., Zakony męskie Królestwa wobec rzeczywistości zaborczej 1815-1864. Kilka problemów badawczych, "Roczniki Humanistyczne” 1974, 22, 2.

Jabłońska-Deptuła E., Gawrysiakowa J., Materiały do zaangażowania patriotycznego zakonów męskich w Królestwie Polskim w latach 1861-1864, w: Materiały do historii zgromadzeń zakonnych na ziemiach polskich w XIX i na poczatku XX wieku, oprac. H. Dylagowa et al., Lublin 1976 [Materiały do Atlasu Historycznego Chrześcijaństwa w Polsce, t. 2, cz. 1].

Kielar P., Rozbiory $i$ kasaty prowincji dominikanów polskich w latach 1772-1914, „Sprawozdania Towarzystwa Naukowego KUL" 1971, 20.

Kowalczyk J., Inwentaryzacja miejsc pamięci powstania styczniowego na terenie województwa świętokrzyskiego (opis obiektów), w: J. Kowalczyk, A. Massalski, T. Wągrowski, W hotdzie przeszłości 1863-1864. Województwo świętokrzyskie, Kielce 2003.

Krucki Ł., Katalog rubrycel i schematyzmów zakonów oraz zgromadzeń zakonnych przechowywanych w księgozbiorze podręcznym Archiwum Archidiecezjalnego w Gnieźnie (1767-2008), „Hereditas Monasteriorum” 2015, 6.

Kubicki P., Bojownicy kapłani za sprawe Kościoła i ojczyzny w latach 1861-1915. Materjały $z$ urzędowych świadectw władz rosyjskich, archiwów konsystorskich, zakonnych i prywatnych, cz. 1, Dawne Królestwo Polskie, t. 3, Diecezje: sandomierska, sejneńska, warszawska, emigracja kleru po r. 1863, zakony, zestawienia i spisy, Sandomierz 1933.

Małecki Z., Sandomierz w latach 1864-1914, w: Dzieje Sandomierza, t. 3, 1795-1914, red. J.M. Małecki, Warszawa 1993.

Massalski A., Miejsce pokuty i poniżenia. Instytut Księży Zdrożnych (1853-1863) i więzienie rosyjskie (1886-1914) na Świętym Krzyżu, w: Klasztor na Świętym Krzyżu w polskiej kulturze narodowej, red. D. Olszewski, R. Gryz, Kielce 2000.

Niebelski E., Nieprzejednani wrogowie Rosji. Duchowieństwo lubelskie i podlaskie w powstaniu 1863 roku i na zesłaniu, Lublin 2008.

Niebelski E., Tunka. Syberyjskie losy księży zesłańców 1863 roku, Wrocław 2011.

Orzechowska E., Aresztowania wśród duchowieństwa diecezji sandomierskiej w dobie powstania styczniowego (1863-1866), „Studia Sandomierskie” 1997-2000, 7.

Orzechowska E., Duchowieństwo diecezji sandomierskiej po wprowadzeniu stanu wojennego do wybuchu powstania styczniowego, „Studia Sandomierskie” 1985-1989, 5. 
Orzechowska E., Duchowieństwo diecezji sandomierskiej w prowincjonalnej organizacji spiskowej przed wybuchem powstania styczniowego (1861-1862), "Studia Sandomierskie" 1983-1984, 4.

Orzechowska E., Duchowni sandomierscy na syberyjskim wygnaniu za udziat w powstaniu styczniowym, „Rocznik Świętokrzyski” 1994, 21.

Orzechowska E., Radomscy bernardyni w dobie powstania styczniowego, Radom 2008.

Orzechowska E., Własność poklasztorna w diecezji sandomierskiej po ukazie z 8 XI 1864 r., "Studia Sandomierskie" 1983, 31, 2.

Patkowski A., Miłość, równość, braterstwo Polaków w Sandomierzu wobec powstania styczniowego, „Ziemia Sandomierska” 1930, 2, 9.

Pietrzak J.S., Księża-powstańcy 1863, Kraków 1913.

Prejs R., Zakonnicy Królestwa Polskiego po kasacie 1864 r. Zagadnienia wybrane, „Nasza Przeszłość" 1997, 88.

Stanaszek B., Duchowieństwo diecezji sandomierskiej w latach 1918-1939, Lublin 1999.

Wiech S., Rola i udział żandarmerii w walce z Kościołem rzymskokatolickim w Królestwie Polskim w latach 1864-1905, „Kwartalnik Historyczny” 2000, 107, 1.

Wiśniewski J., Katalog prałatów i kanoników sandomierskich od 1186-1926 r. tudzież sesje kapituty sandomierskiej od 1581 do 1866 r., Radom 1926.

Wiśniewski J., Udział księży z diecezji sandomierskiej w Powstaniu Styczniowym 1863, Radom 1926.

Wójcik W., Domy demerytów w Królestwie Polskim (1836-1885), „Prawo Kanoniczne” 1981, $24,3-4$.

Wójcik W., Tak zwana reforma klasztorów w 1864 roku na terenie diecezji sandomierskiej, „Archiwa, Biblioteki i Muzea Kościelne" 1971, 23.

Wójcik W., Włączenie zbiorów poklasztornych do Biblioteki Seminarium Duchownego w Sandomierzu, „Archiwa, Biblioteki i Muzea Kościelne” 1960, 1, 2.

Wyrzykowski A., Buliński Melchior, w: Polski Słownik Biograficzny, t. 3, Kraków 1937.

\section{NOTA O AUTORZE}

Dominika Burdzy - dr nauk humanistycznych, adiunkt Instytutu Historii Uniwersytetu Jana Kochanowskiego w Kielcach. Autorka publikacji z zakresu historii Kościoła katolickiego oraz mieszczaństwa w okresie późnego średniowiecza i nowożytności. Jej zainteresowania badawcze koncentrują się głównie na dziejach zakonu dominikanów i jezuitów oraz miast małopolskich (ze szczególnym uwzględnieniem Sandomierza). 